\title{
Dopamine Receptor mRNA Expression Patterns by Opioid Peptide Cells in the Nucleus Accumbens of the Rat: A Double In Situ Hybridization Study
}

\author{
EILEEN J. CURRAN AND STANLEY J. WATSON, JR. \\ University of Michigan Mental Health Research Institute, Ann Arbor, Michigan 48109-0720
}

\begin{abstract}
Colocalization of proenkephalin and prodynorphin mRNAs with each other as well as with $\mathrm{D} 1, \mathrm{D} 2$, and D3 dopamine receptor mRNAs was analyzed in the nucleus accumbens of the rat. Distinct combinations were detected in the rostral pole, core, and shell subdivisions of the nucleus accumbens. Proenkephalin and prodynorphin mRNAs were principally localized in separate cells in the core. All detectable prodynorphin cells in the core expressed D1 mRNA but not D2 mRNA. Conversely, approximately $95 \%$ of the proenkephalin-positive cells in this region expressed D2 mRNA but not D1 mRNA. This pattern was identical to that observed in the caudate putamen. In the rostral pole and the shell, embedded in a background of this "typical" colocalization pattern, clusters of cells expressing a distinct configuration were found. In these clusters, proenkephalin-positive cells expressed both prodynorphin and D1 mRNAs, but they did not express D2 mRNA.

D3 and prodynorphin mRNAs were colocalized in "limbic" striatal areas, including the ventromedial caudate putamen, the rostral pole, and the medial shell. In contrast, D3 mRNA was not detected in any proenkephalin-positive cells. Together with the prodynorphin/D1 data, this suggests that a subset of prodynorphin cells expresses both D1 and D3 mRNAs.

It is concluded that 1) clusters of cells that coexpress proenkephalin, prodynorphin, and D1 mRNAs overlap extensively with previously defined cytoarchitectural cell clusters in the nucleus accumbens and 2) a subset of the prodynorphin cells in the ventromedial caudate putamen and the nucleus accumbens contains both D1 and D3 mRNAs. 1995 Wiley-Liss, Ine.
\end{abstract}

Indexing terms: $\mathrm{D} 1$ receptor, $\mathrm{D} 2$ receptor, $\mathrm{D} 3$ receptor, striatum

The nucleus accumbens (NAcc) is a major component of the ventral striatum (Heimer et al., 1982), which has been implicated in a number of functions, including drug reinforcement and locomotor behavior (Koob et al., 1991). Dopamine (DA) and the opioid peptides are two neurotransmitter systems within the NAcc that have been associated with these functions (Cooper, 1991). The NAcc is rich in the opioid peptides enkephalin (ENK) and dynorphin (DYN) as well as DA terminals and DA receptors. Analyses of the DA receptor subtypes expressed by ENK and DYN cells have, however, focused mainly on the caudate putamen $(\mathrm{CPu}$; Gerfen, 1992; Surmeier et al., 1993). The NAcc shares a number of neurochemical and anatomical characteristics with the $\mathrm{CPu}$, but behavioral studies have indicated that these two nuclei are functionally distinct. Furthermore, DA-opioid interactions within the NAcc produce distinct behavioral effects compared to those of the $\mathrm{CPu}$ (for references, see Cooper, 1991; Koob et al., 1991; Wise and Hoffman, 1992; Bals-Kubik et al., 1993), suggesting that the opioid peptide/DA receptor colocalization patterns might differ between these two nuclei.

Immunohistochemical studies indicate that ENK and DYN peptides are localized primarily in separate populations of GABAergic projection neurons throughout the striatal complex (Anderson and Reiner, 1990; Reiner and Anderson, 1990). There is also evidence indicating that ENK and DYN are differentially expressed by the two major output pathways of the CPu (Gerfen et al., 1990; Reiner and Anderson, 1990). The majority of the neurons projecting to the globus pallidus (striatopallidal pathway) contain ENK, whereas the majority of the cells projecting to the entopeduncular nucleus and/or the substantia nigra (commonly grouped together as the striatonigral pathway)

\footnotetext{
Accepted March 22, 1995.

Address reprint requests to Eileen J. Curran, University of Michigan Mental Health Research Institute, 205 Zina Pitcher Place, Ann Arbor, MI 48109-0720.
} 
contain DYN. Comparisons of the parallel outputs of the NAcc to the ventral pallidum (VP) and the ventral tegmental area (VTA) are not as clear, but immunohistochemical studies suggest that the NAcc-VTA pathway may be similar to the striatonigral pathway, because there are large numbers of DYN-positive fibers within the VTA with far fewer ENK-positive fibers (Fallon et al., 1985; Kalivas et al., 1993). NAcc projections to the VP may be more complex than the striatopallidal projections, because the VP has been found to share characteristics with both the globus pallidus and the entopeduncular nucleus (Haber and Nauta, 1983; Haber et al., 1985). In addition, the distribution of ENK and DYN immunoreactivity within the VP has been described as overlapping but distinguishable, implying that there could be populations of NAcc-VP cells that contain both ENK and DYN as well as populations that contain only one of these peptides (Haber and Watson, 1985). Both colocalization and tract-tracing studies must be conducted to test this hypothesis.

At present, there are five known DA receptors that potentially could be expressed by the striatal ENK and DYN cells. These include D1, D2, D3, D4, and D5 receptors (Civelli et al., 1991). Pharmacologically, these five DA receptors can be resolved only into two major families, the D1-like (which includes D1 and D5 receptors) and the D2-like (D2, D3, and D4). Binding studies have found that both D1-like and D2-like receptors are abundant in the CPu and the NAcc (Boyson et al., 1986; Mansour et al., 1990). In situ hybridization studies have further characterized the striatal DA receptors, showing that D1 and D2 receptor mRNAs are the most abundant and widely distributed in the $\mathrm{CPu}$ and the NAcc (Meador-Woodruff et al., 1989; Civelli et al., 1991; Mansour et al., 1991). D3 receptor mRNA is also present in these nuclei, although it is less abundant, and its distribution is restricted to the ventromedial $\mathrm{CPu}$ and to parts of the NAcc (Sokoloff et al., 1990, 1992; Bouthenet et al., 1991 Mansour and Watson, 1995). D4 and D5 receptor mRNAs are thought to be present in the striatal complex of some species; however, in the rat, either these mRNAs are not present or their levels are so low that they are not detectable with current in situ hybridization techniques (Sunahara et al., 1991; Van Tol et al., 1991; Meador-Woodruff et al., 1992).

DA receptor expression by ENK and DYN projection neurons of the CPu is a topic of controversy (see Gerfen, 1992; Surmeier et al., 1993), but a number of studies suggest that there are distinctions. For example, selective lesions of the striatopallidal pathway decrease D2 binding to a much greater extent than $\mathrm{D} 1$ binding in the $\mathrm{CPu}$, whereas lesions of the striatonigral pathway decrease D1 but have no effect on D2 binding (Harrison et al., 1992; Pollack et al., 1993). In addition, tract-tracing and/or in situ hybridization studies have shown that proenkephalin and D2 mRNAs are principally coexpressed in striatopallidal cells, whereas prodynorphin and D1 mRNAs are principally coexpressed in striatonigral cells (Gerfen et al., 1990; Le Moine et al., 1990, 1991). It remains to be determined, however, whether these opioid peptide/DA receptor relationships extend into the NAcc. Furthermore, the expression of D3 mRNA by DYN and/or ENK cells has not been examined in either the CPu or the NAcc.

D1, D2, and D3 receptor mRNAs and/or proteins have distinct distributions within the NAcc, suggesting that there may be differences in the expression of these three DA receptors by ENK and DYN cells within subregions of this nucleus. The heterogeneous distribution of a number of neuroactive substances within the NAcc has led to the breakdown of this nucleus into three major subdivisions, which are termed the core, the shell, and the rostral pole (Groenewegen and Russchen, 1984; Zaborsky et al., 1985; Groenewegen et al., 1991; Heimer et al., 1991; Zahm and Brog, 1992) The rostral pole encompasses the most anterior portion of the NAcc before the anterior commissure begins to move medially away from the external capsule (Zahm and Brog, 1992). Core/shell distinctions are made in the middle and caudal one-third of the NAcc, with the core being centered somewhat asymmetrically around the anterior commissure and the shell surrounding the core (Zahm and Brog, 1992). Tract-tracing studies have found that the core receives information from limbic cortical areas (Phillipson and Griffiths, 1985; McDonald, 1991; Brog et al., 1993) but projects to a number of motor output structures, including the subthalamic nucleus, the substantia nigra, and the entopeduncular nucleus, three regions closely associated with the $\mathrm{CPu}$ (Groenewegen and Russchen, 1984; Zahm and Heimer, 1990, 1993; Heimer and Alheid, 1991; McDonald, 1991; Brog et al., 1993). In contrast, the shell is interconnected with more limbic structures, including the VTA, the lateral hypothalamus, and the medial prefrontal cortex, three additional regions linked to drug reinforcement (Groenewegen and Russchen, 1984; Heimer et al., 1991). The rostral pole appears to share characteristics with both the core and the shell (Zahm and Brog, 1992; Zahm and Heimer, 1993). Interestingly, projection neurons within these anatomically distinct subregions of the NAcc may express different combinations of DA receptors. D1 and D2 receptor immunoreactivity patterns are heterogeneous within the NAcc (Levey et al., 1993), and binding studies suggest that the ratio of D1-like receptors to D2-like receptors is greater in the shell than in the core (Bardo and Hammer, 1991). Furthermore, D3 receptor mRNA is expressed primarily in the rostral pole and the dorsomedial shell, with little expression observed in the core (Bouthenet et al., 1991; Mansour and Watson, 1995). These findings suggest that the opioid peptide/DA receptor colocalization patterns may differ not only between the CPu and the NAcc but also among the three major subdivisions of the NAcc.

The goal of this study was to develop a map detailing the colocalization of the opioid peptides ENK and DYN with $\mathrm{D} 1, \mathrm{D} 2$, and D3 receptors in the NAcc of the rat. Double in situ hybridization methods were used to examine the coexpression patterns of prodynorphin and proenkephalin mRNAs with each other as well as with the three DA receptor mRNAs. Colocalization patterns detected in the $\mathrm{CPu}$ as well as the rostral pole, the core, and the shell of the NAcc were compared in order to determine possible differences among these anatomically distinct regions. These comparisons revealed some similarities between the $\mathrm{CPu}$ and the NAcc, but unique colocalization patterns were observed in the rostral pole and shell subdivisions of the NAcc.

\section{MATERIALS AND METHODS Tissue preparation}

Tissue was obtained from ten adult male Sprague-Dawley rats (250-350 g; Charles River) that were quickly decapitated. This procedure was conducted in accordance with the University of Michigan animal use protocols. The brains were removed and frozen in isopentane at $-30^{\circ} \mathrm{C}$ for 30 
TABLE 1. Riboprobe Data and Source

\begin{tabular}{llll}
\hline Riboprobe & $\begin{array}{c}\text { Size } \\
\text { (bases) }\end{array}$ & \multicolumn{1}{c}{ Insert $^{1}$} & \multicolumn{1}{c}{ Reference } \\
\hline Proenkephalin & 693 Bases & Exon 3 & Yoshikawa et al,, 1984 \\
Prodynorphin & 733 Bases & Exon 4 & Civelli et al., 1985 \\
D1 receptor & 530 Bases & TM III-IV & Zhou et al., 1990 \\
D2 receptor & 495 Bases & TM VI-VII & Bunzow et al., 1988 \\
D3 receptor & 325 Bases & Third cytoplasmic loop & Sokoloff et al., 1990 \\
\hline \multicolumn{2}{l}{ ITM, transmembrane. }
\end{tabular}

TM, transmembrane.

seconds then stored at $-80^{\circ} \mathrm{C}$ until they were cut on a Bright cryostat maintained at $-20^{\circ} \mathrm{C}$. Ten micrometer coronal sections were cut through the rostrocaudal extent of the NAcc and CPu, thaw-mounted onto polylysinesubbed slides, and stored at $-80^{\circ} \mathrm{C}$ until used for in situ hybridization.

\section{Probe labeling}

Riboprobes complementary to proenkephalin, prodynorphin, D1 receptor, D2 receptor, and D3 receptor mRNAs were used in both single and double in situ hybridization studies (for details, see Table 1). Radioactive riboprobes for proenkephalin, prodynorphin, D1, and D2 were generated by labeling with $250 \mu \mathrm{Ci}$ of ${ }^{35} \mathrm{~S}-\mathrm{UTP}$ (NEN) using $1 \mu \mathrm{l}$ of the appropriate RNA polymerase in a $25 \mu$ l transcription reaction containing $5 \mu \mathrm{l} 5 \times$ transcription buffer; $2 \mu \mathrm{l} 0.1 \mathrm{M}$ dithiothreitol; $12 \mu \mathrm{l}$ sterile water; $1 \mu$ l linearized plasmid ( 1 $\mu \mathrm{g} / \mu \mathrm{l}) ; 1 \mu \mathrm{l}$ each of $10 \mathrm{mM}$ stocks of ATP, CTP, and GTP; and $1 \mu \mathrm{l}$ of RNasin. The transcription reaction was incubated for 2 hours at $37^{\circ} \mathrm{C}$, and then the labeled probe was separated from unincorporated nucleotides on a SephadexG50 column. Radioactive D3 riboprobes were generated in a similar manner, except that this probe was labeled with both ${ }^{35} \mathrm{~S}-\mathrm{UTP}$ and ${ }^{35} \mathrm{~S}-\mathrm{CTP}$ to enhance the signal for this relatively rare mRNA. In the double in situ studies, either the riboprobes were labeled with ${ }^{35} \mathrm{~S}$ as described above, or they were labeled with a digoxigenin-UTP (dig-UTP; Boehringer Mannheim). This transcription reaction was performed as recommended by Boehringer Mannheim; in a 20 $\mu$ l final volume, $4 \mu \mathrm{l} 5 \times$ transcription buffer, $2 \mu l 0.1 \mathrm{M}$ dithiothreitol, $9 \mu$ l sterile water, $1 \mu$ l linearized plasmid, 2 $\mu \mathrm{l}$ rNT mix (containing $2 \mu \mathrm{l}$ each of $10 \mathrm{mM}$ ATP, CTP, and GTP; $1.3 \mu \mathrm{l} 10 \mathrm{mM}$ UTP; and $0.7 \mu \mathrm{l} 10 \mathrm{mM}$ dig-UTP), $1 \mu \mathrm{l}$ RNA polymerase, and $1 \mu \mathrm{l}$ RNasin were added. The transcription reaction was incubated at $37^{\circ} \mathrm{C}$ for 2 hours and was then separated on a G50/50 column. The fraction containing the dig-labeled riboprobe was determined by a small-scale color reaction (see below) run on $1 \mu$ l aliquots of G50/50 fractions blotted onto nytran paper.

\section{Single in situ hybridization studies}

Single radioactive in situ hybridization studies were conducted to develop a distribution map for the proenkephalin, prodynorphin, D1, and D2 mRNAs. Representative adjacent sections through the rostral, middle, and caudal extent of the NAcc and the overlaying CPu were hybridized with one of the four probes. The order of the probes used for hybridization was alternated so that they would be next to all of the other three probes at least twice for each rostrocaudal level. In a separate study, the distribution of D3 mRNA was analyzed in relation to the opioid peptides. Single radioactive in situ hybridization studies were also conducted for all five of these probes on sections adjacent to those used in the double in situ hybridization experiments. This was done to make sure that the distribution of silver grains within the striatal nuclei was not altered for a given probe by the addition of a second nonradioactive probe (see in situ hybridization controls below).

Prior to hybridization, the sections were removed from storage at $-80^{\circ} \mathrm{C}$ and placed in 4 grams $\%$ paraformaldehyde for 1 hour at room temperature (RT). The slides were washed three times in $2 \times \mathrm{SSC}(300 \mathrm{mmol} /$ liter $\mathrm{NaCl}, 30$ $\mathrm{mmol} /$ liter sodium citrate, $\mathrm{pH} 7.2$ ), treated with proteinase $\mathrm{K}(1 \mu \mathrm{g} / \mathrm{ml})$ for 10 minutes at $37^{\circ} \mathrm{C}$, rinsed in water, and acetylated in triethanolamine and acetic anhydride $(0.25 \%)$ for 10 minutes at RT. Following acetylation, the slides were rinsed in $2 \times$ SSC and dehydrated through graded alcohols.

Hybridization and posthybridization steps for the radioactive in situ hybridization studies were as previously described (Watson et al., 1988). Briefly, the ${ }^{35}$ S-riboprobes were diluted in hybridization buffer to a final concentration of $1-2 \times 10^{6} \mathrm{dpm}$ per $35 \mu \mathrm{l}$. The hybridization buffer contained $50 \%$ formamide, $10 \%$ dextran sulfate, $3 \times \mathrm{SSC}$, $50 \mathrm{mM}$ phosphate buffer (pH 7.4), $1 \times$ Denhardt's solution (0.02\% polyvinyl pyrrolidone, $0.02 \%$ Ficoll, $0.02 \%$ bovine serum albumin), $0.1 \mathrm{mg} / \mathrm{ml}$ yeast tRNA, and $10 \mathrm{mM}$ dithiothreitol. 'The tissue sections were apposed to the diluted probe with coverslips and then placed in a hybridization box containing Whatman filter paper moistened with $50 \%$ formamide. The hybridization boxes were then sealed and placed in a $55^{\circ} \mathrm{C}$ oven overnight. The next day, the coverslips were removed with $2 \times$ SSC. The sections were washed three times in $2 \times \mathrm{SSC}$, treated with $200 \mu \mathrm{g} / \mathrm{ml}$ RNase A at $37^{\circ} \mathrm{C}$ for 1 hour; rinsed once for 5 minutes each in $2 \times \mathrm{SSC}, 1 \times \mathrm{SSC}$, and $0.5 \times \mathrm{SSC}$; washed for 1 hour at $70^{\circ} \mathrm{C}$ in $0.1 \times \mathrm{SSC}$; rinsed for 5 minutes in water at RT; and then dehydrated through graded alcohols. Dried slides were apposed to $x$-ray film for 1-20 days depending on the abundance of the target mRNA. These films were used to examine the macroscopic distribution of each mRNA of interest. Following apposition to $\mathrm{x}$-ray film, each slide was dipped in NTB-2 emulsion, dried, and stored at $4^{\circ} \mathrm{C}$. Dipped slides were developed according to times determined by test slides, counterstained with cresyl violet, and used to examine the cellular distribution of each mRNA.

\section{Double in situ hybridization studies}

The proenkephalin and the prodynorphin riboprobes were labeled with dig-UTP as described above. These probes were then hybridized simultaneously with $\mathrm{D} 1, \mathrm{D} 2$, D3, proenkephalin, or prodynorphin ${ }^{35} \mathrm{~S}$-labeled riboprobes. Colocalization maps of the three DA receptor mRNAs with the opioid peptide mRNAs and of proenkephalin and prodynorphin mRNAs with each other were developed using adjacent sections through the rostrocaudal extent of the NAcc and the overlaying $\mathrm{CPu}$.

The method for the double in situ hybridization experiments was similar to the single radioactive in situ method but included a few changes. First, during the hybridization step, a dig-labeled riboprobe was diluted in $50 \%$ hybridization buffer together with a ${ }^{35}$ S-labeled riboprobe. Second, following the last posthybridization SSC wash in the abovedescribed protocol, the sections were incubated in a blocking solution $(0.1 \mathrm{M}$ phosphate buffer, $0.25 \%$ carrageenan, $0.5 \%$ Triton-X 100, $\mathrm{pH} 7.4$ ) at RT for 1 hour. The sections were then incubated overnight at $R T$ with an alkaline phosphatase (AP)-conjugated antidig (sheep antidig-AP, Fab fragments; Boehringer Mannheim) diluted 1:5,000-1: 30,000 in blocking solution. The next day, the sections were washed extensively in $0.1 \mathrm{M}$ phosphate buffer, $\mathrm{pH} 7.4$, 
followed by two 10 minute washes in Tris-buffered saline, pH 7.5, and one 5 minute wash in alkaline substrate buffer (ASB; $100 \mathrm{mM}$ Tris base, $150 \mathrm{mM} \mathrm{NaCl}, 50 \mathrm{mM} \mathrm{MgCl}_{2}, \mathrm{pH}$ 9.5). The slides then underwent a color reaction in ASB containing $5 \%$ polyvinyl alcohol (w:vol; Sigma; De Block and Debrouwer, 1993), 0.45\% NBT (vol:vol; Boehringer Mannheim), 0.35\% BCIP (vol:vol; Boehringer Mannheim), and $0.024 \%$ levamisole (w:vol; Sigma). The slides were examined under a microscope to determine when the color reaction was completed, with the time ranging from 2 to 10 hours. Following the color reaction, the slides were washed extensively in water, dehydrated quickly in graded alcohols, and air dried. Slides were apposed to $\mathbf{x}$-ray film to visualize the ${ }^{35}$ S-labeled riboprobe and then dipped in Ilford KD-5 emulsion (Polysciences). The dipped slides were sealed in light-tight boxes and stored at $4^{\circ} \mathrm{C}$ and were then developed following periods (determined with test slides) ranging from 1 to 8 weeks. The cellular distributions of the radioactive (silver grains) and nonradioactive (purple precipitate) riboprobes were simultaneously visualized with a Zeiss Axiophot microscope.

\section{Data analysis}

The distribution of each mRNA was qualitatively examined within the CPu and the NAcc in both the single and the double in situ hybridization studies. Those mRNAs with similar distributions were further analyzed in the double in situ studies by cell counts using an adaptation of the fractionator method (Gundersen et al., 1988) to estimate the percentage of colocalization. To help determine whether there were regional differences within the NAcc, estimates of the rostral pole, core, and shell boundaries were made based on those described in the rat atlas of Paxinos and Watson (1986). The CPu, on the other hand, was subdivided into dorsolateral, dorsomedial, ventrolateral, and ventromedial quadrants. Cell counts were conducted in each of these NAcc and CPu compartments. First, within each compartment at four rostrocaudal levels, random populations of cells were defined using a $250 \times 250 \mu \mathrm{m}$ grid at $\times 400$ magnification; second, the dig-labeled cells in the grid were counted; third, the ${ }^{35} \mathrm{~S}$-labeled cells in the grid were counted; and fourth, the number of cells containing both the dig-and the ${ }^{35} \mathrm{~S}$ signals were counted. These counts were then used to estimate the percentage of colocalization for the two mRNAs in both the CPu and the NAcc. The D3 mRNA signal was very low and, in some regions, was not easily distinguishable from background, making the data from these double in situ experiments incompatible with cell counts. The data for this DA receptor, therefore, are more qualitative, descriptions being limited to areas of high D3 signal that overlap with the opioid peptide mRNAs.

\section{Specificity controls}

RNase and/or sense-strand controls produced no specific signal for the DA receptor $m R N A s$ and the opioid peptide mRNAs, as has been shown previously (Mansour et al., 1990, 1991; Schafer et al., 1990; Day et al., 1993; Mansour and Watson, 1995). For the dig-labeled proenkephalin and prodynorphin probes, comparisons of the radioactive and nonradioactive signals revealed no differences in signal distribution. Furthermore, double in situ hybridization studies using the same riboprobe labeled with ${ }^{35} \mathrm{~S}$ and dig produced double-labeled cells (see Results). For all radioactive probes, single in situ experiments were conducted on sections adjacent to those that were used for double in situ studies to confirm that the distribution of the radioactive probe was not altered by the presence of the nonradioactive probe (i.e., quenching of the radioactive signal by the nonradioactive signal).

\section{RESULTS Single in situ hybridization}

Analysis of the autoradiograms from the single radioactive in situ hybridization experiments (as well as the double in situ experiments) revealed similar distribution patterns for prodynorphin, proenkephalin, D1 receptor, and D2 receptor $\mathrm{mRNAs}$ within the $\mathrm{CPu}$ and the NAcc. All four of these mRNAs were relatively abundant in both the $\mathrm{CPu}$ and the NAcc, as can be seen in Figures 1 and 2. There were, however, subtle distinctions in the distribution of these mRNAs in both nuclei. For example, proenkephalin, D1 receptor, and D2 receptor signals were homogeneous within the $\mathrm{CPu}$, but prodynorphin signal was present in a patchy pattern. This has been described previously and is attributed to a higher prodynorphin signal per cell within the striosomes of the CPu compared to prodynorphin-positive cells within the surrounding matrix (Gerfen et al., 1991). Within the NAcc, the distribution patterns for all four of these messages were more complex, with areas of high signal intensity standing out against areas of low or no signal. This was especially clear in more rostral sections, where proenkephalin, prodynorphin, and D1 receptor signals were high in the ventral NAcc, but D2 receptor signal was absent (cf. Figs. 1 and 2). In comparison to the four other mRNAs, D3 receptor mRNA signal was weak and had a restricted distribution (Fig. 3). The islands of Calleja had the greatest D3 receptor signal intensity, but these structures did not express either opioid peptide mRNA. In the $\mathrm{CPu}$, overlap between the opioid peptides and the D3 receptor occurred within the ventromedial aspect of this nucleus. Within the NAcc, D3 receptor signal was relatively robust within the rostral pole and the dorsomedial shell, whereas it was much lower in the core.

\section{Double in situ hybridization analysis of the CPu}

Control experiments indicated that the distribution patterns generated with the nonradioactive in situ hybridization procedure for both the proenkephalin and the prodynorphin mRNAs were indistinguishable from those obtained using the standard radioactive procedure. Furthermore, as can be seen in Figure 4A, cohybridization of an ${ }^{35}$ S-labeled proenkephalin probe with a dig-labeled proenkephalin probe produced double-labeled cells.

Fig. 1. Darkfield autoradiograms of proenkephalin (Enk; A-D) mRNA and prodynorphin (Dyn; $\mathbf{A}^{\prime}-\mathbf{D}^{\prime}$ ) mRNA in $10 \mu \mathrm{m}$ coronal sections at four rostrocaudal levels through the nucleus accumbens (NAce) and the overlaying caudate putamen $(\mathrm{CPu})$. The proenkephalin and prodynorphin in situ hybridization experiments were conducted on adjacent or semiadjacent sections (these sections were run in a series of four along with the D1 and D2 riboprobes shown in Fig. 2). Note the areas of high signal intensity for both mRNAs within the rostroventral $\mathrm{NAcc}$ in $\mathrm{A}$ and $\mathrm{B}$ (see arrow in A for reference). More caudally, this large area separated into smaller clusters $(C, D)$; these are especially visible at this magnification along the lateral edge of the NAcc extending into the fundus striati (see arrow in $\mathrm{C}$ for reference). The midline is to the right in all panels. Scale bar $=\mathbf{1 . 5} \mathrm{mm}$. 

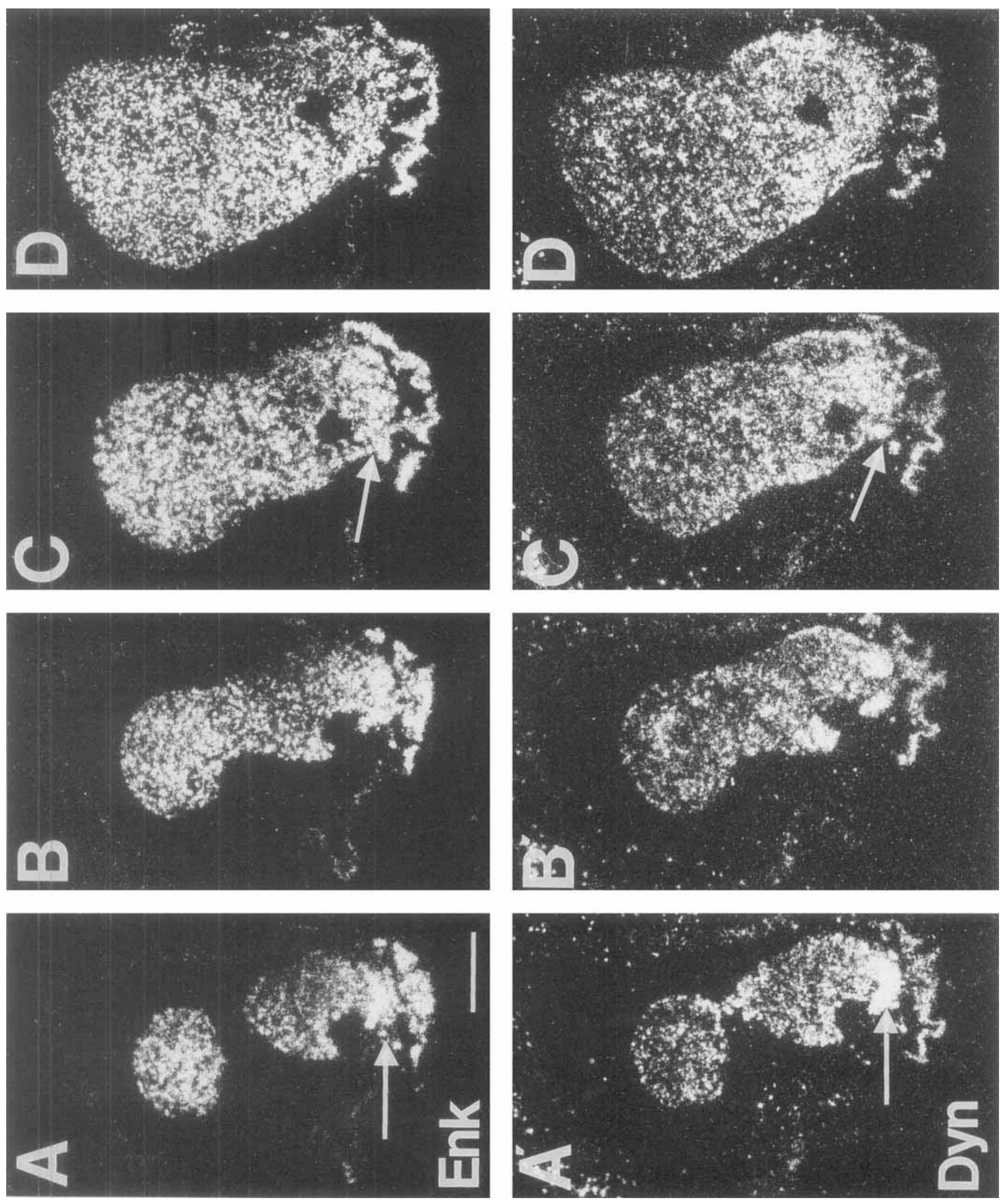

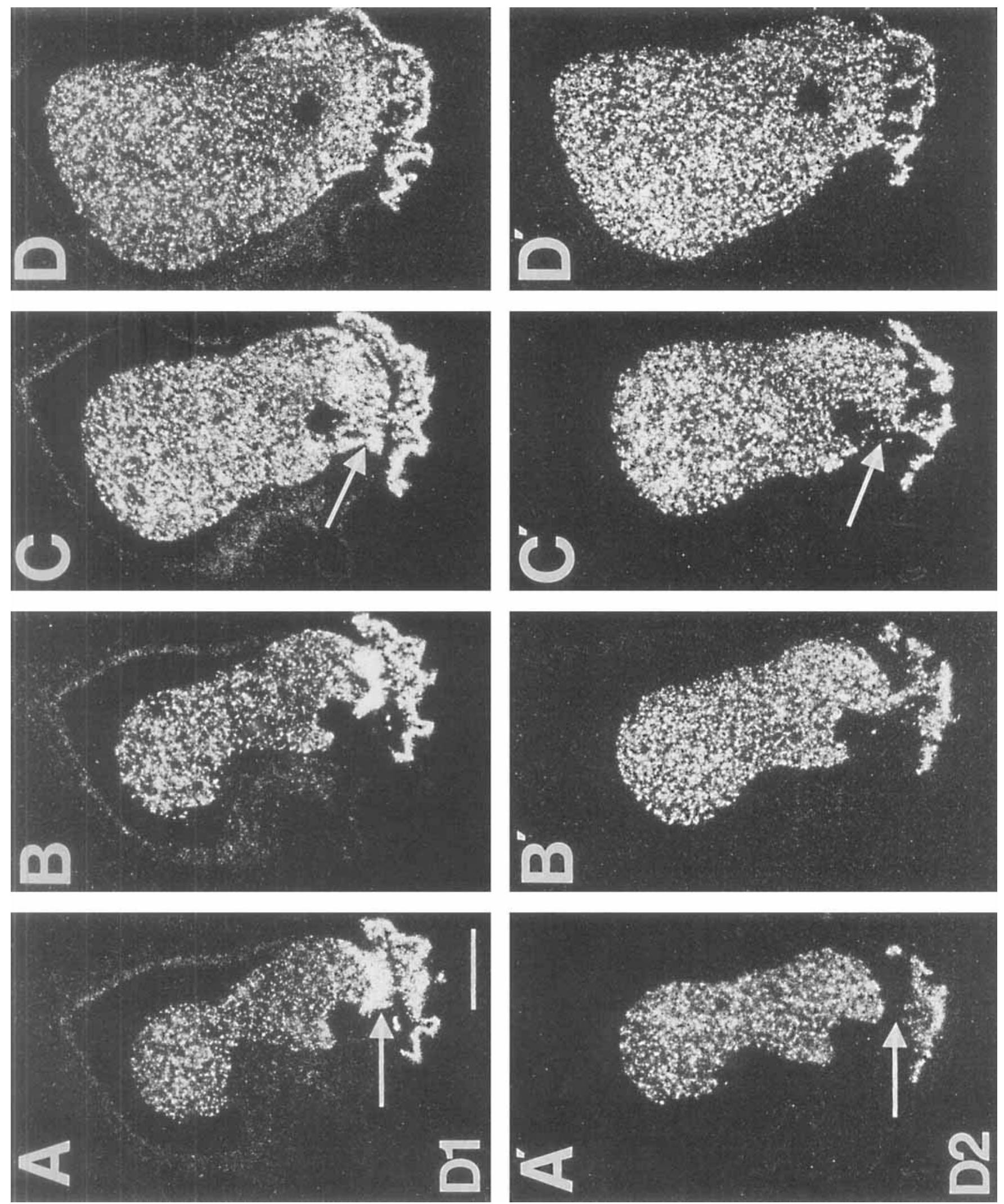
The double in situ hybridization studies comparing the distributions of proenkephalin and prodynorphin mRNAs within the $\mathrm{CPu}$ revealed that these two opioid peptide mRNAs were primarily in separate cell populations (Fig. 4B). Only a small number of the proenkephalin-positive cells within the $\mathrm{CPu}(<5 \%)$ coexpressed prodynorphin mRNA and vice versa (Fig. 5). These double-labeled opioid peptide cells were scattered throughout the $\mathrm{CPu}$, with no apparent regional differences.

Cohybridization of the opioid peptide riboprobes with DA receptor riboprobes suggested that proenkephalin- and prodynorphin-positive cells within the CPu differentially express D1 and D2 receptor mRNAs. Figure 6A shows that D1 receptor and proenkephalin mRNAs were principally in separate cells within the $\mathrm{CPu}$ (see Fig. 7 for reference). However, cell counts revealed a small number of isolated proenkephalin-positive cells that expressed D1 receptor mRNA and vice versa (Fig. 5). In contrast, approximately 95\% of the proenkephalin cells within the CPu expressed D2 receptor mRNA, and over $90 \%$ of the D2-positive cells expressed proenkephalin mRNA (Figs. 5, 6B). It could not be determined in adjacent sections whether the proenkephalin/D2-negative cells corresponded to the proenkephalin/D1positive cells, because both populations were rare and were scattered through the nucleus. Double in situ hybridization analysis of prodynorphin $\mathrm{mRNA}$ with $\mathrm{D} 1$ or $\mathrm{D} 2$ receptor mRNA indicated that the opposite DA receptor pattern exists for prodynorphin-positive cells within the $\mathrm{CPu}$. All observable prodynorphin-positive cells expressed D1 receptor mRNA (Fig. 6D), whereas none of these cells coexpressed D2 receptor mRNA (Fig. 6E). The number of D1-positive cells detected within the CPu was greater than the number of prodynorphin cells, leaving approximately $10 \%$ of the D1 receptor cells prodynorphin-negative (Fig. 5).

Colocalization of D3 receptor mRNA with proenkephalin or prodynorphin mRNAs was difficult because of its low abundance. However, groups of D3-positive cells had relatively high signal in the ventromedial $\mathrm{CPu}$, the dorsomedial rostral pole, and the medial shell. Within these regions, D3 receptor and proenkephalin mRNAs were not colocalized (Fig. 6C), but a large number of these D3-positive cells did express prodynorphin mRNA (Fig. 6F). These data, combined with the observation that all prodynorphin-positive cells coexpressed D1 receptor mRNA, suggest that there is a subpopulation of prodynorphin cells that coexpress D1 and D3 receptor mRNAs.

\section{Double in situ hybridization analysis of the NAcc}

The double in situ hybridization experiments revealed that the NAcc, in contrast to the $\mathrm{CPu}$, contained a number of cells that coexpressed the opioid peptide mRNAs. Clusters of cells located within the rostral pole and the shell subdivisions of the NAcc expressed both proenkephalin and prodynorphin mRNAs (Figs. 6I, 8A). However, in the core of the NAcc and in regions of the rostral pole and shell

Fig. 2. Darkfield autoradiograms of D1 (A-D) and D2 $\left(\mathbf{A}^{\prime}-\mathbf{D}^{\prime}\right)$ receptor mRNAs in sections adjacent or semiadjacent to sections shown in Figure 1. Note that areas of high signal intensity for D1 receptor mRNA overlap with those seen for proenkephalin and prodynorphin (see arrows in $\mathrm{A}$ and $\mathrm{C}$ for reference). D2 receptor $\mathrm{mRNA}$, on the other hand, is not expressed in these regions (see arrows in $\mathrm{A}^{\prime}$ and $\mathrm{C}^{\prime}$ ). Scale bar $=1.5 \mathrm{~mm}$. surrounding these unique cell clusters, the distribution of the opioid peptide mRNAs mirrored that of the CPu: In these regions, the opioid peptide mRNAs were primarily in separate cell populations (Fig. 5). Analysis of adjacent sections revealed that the proenkephalin cells within the opioid peptide cell clusters did not express D2 receptor mRNA (Figs. 6H, 8B). Interestingly, the proenkephalin cells located in these cell clusters did express D1 receptor mRNA (Figs. 6G, 9A). Furthermore, the prodynorphin cells present within these cell clusters, like those outside the clusters, expressed D1 receptor mRNA but not D2 receptor mRNA (data not shown). However, the proenkephalin cells outside the cell clusters displayed the standard CPu-like colocalization pattern (see Fig. 5): These proenkephalin cells primarily coexpressed D2 receptor mRNA but not D1 receptor mRNA (Figs. 6H, 9B). Together, these data suggest that there are clusters of cells scattered through the NAcc that coexpress both opioid peptide mRNAs as well as D1 receptor mRNA but are devoid of D2 receptor mRNA (proenkephalin/prodynorphin/D1 cell clusters). In addition, the core of the NAcc and regions surrounding the proenkephalin/prodynorphin/D1 cell clusters have opioid peptide/DA receptor colocalization patterns similar to those of the $\mathrm{CPu}$ (Fig. 5).

The distribution of the proenkephalin/prodynorphin/D1 cell clusters is illustrated in Figure 10. The ventral portion of the rostral pole contained a large cluster of proenkephalin/ prodynorphin/D1 cells (Fig. 10B). Rostromedial and caudolateral portions of the olfactory tubercle appeared to have extensions of this cluster. In more caudal sections, the ventral proenkephalin/prodynorphin/D1 cluster appeared to separate into smaller clusters that were dispersed through the shell subregion of the NAcc (Fig. 10A,C-E). One of these smaller clusters was present along the lateral edge of the NAcc and extended caudally into the fundus striati (Fig. 10E). This lateral cluster was still apparent in the most caudal sections examined in this study (Bregma $0.48 \mathrm{~mm}$ in Paxinos and Watson, 1986). Other proenkephalin/prodynorphin/D1 cell clusters existed within the medial and ventral portions of the NAcc along the core/shell border or in proximity to the islands of Calleja (Fig. 10C-E; compare also to Fig. 11).

Examination of the proenkephalin/prodynorphin/D1 cell cluster regions in single in situ hybridization studies supported the double in situ hybridization data. Figures 1 and 2 show that the signal intensities for the opioid peptide mRNAs and the D1 receptor mRNA were higher in regions that overlap with the proenkephalin/prodynorphin/D1 cell clusters (compare to Fig. 10). This was especially visible in the ventral zone of the rostral pole and along the lateral edge of the NAcc extending back into the fundus striati (see arrows in Figs. 1, 2). These regions were devoid of D2 receptor mRNA signal (Fig. 2). An inspection of these regions at the cellular level (in dipped sections counterstained with cresyl violet) indicated that the proenkephalin/ prodynorphin/D1 cell clusters corresponded to areas of densely packed Nissl-stained cells compared to surrounding regions (Fig. 11).

The autoradiograms for D3 receptor mRNA (Fig. 3) suggested that, at least within the ventral region of the rostral pole, D3 receptor mRNA may be present in the proenkephalin/prodynorphin/D1 cell clusters. A further analysis of these regions in emulsion-dipped sections from either the single or the double in situ hybridization experi- 

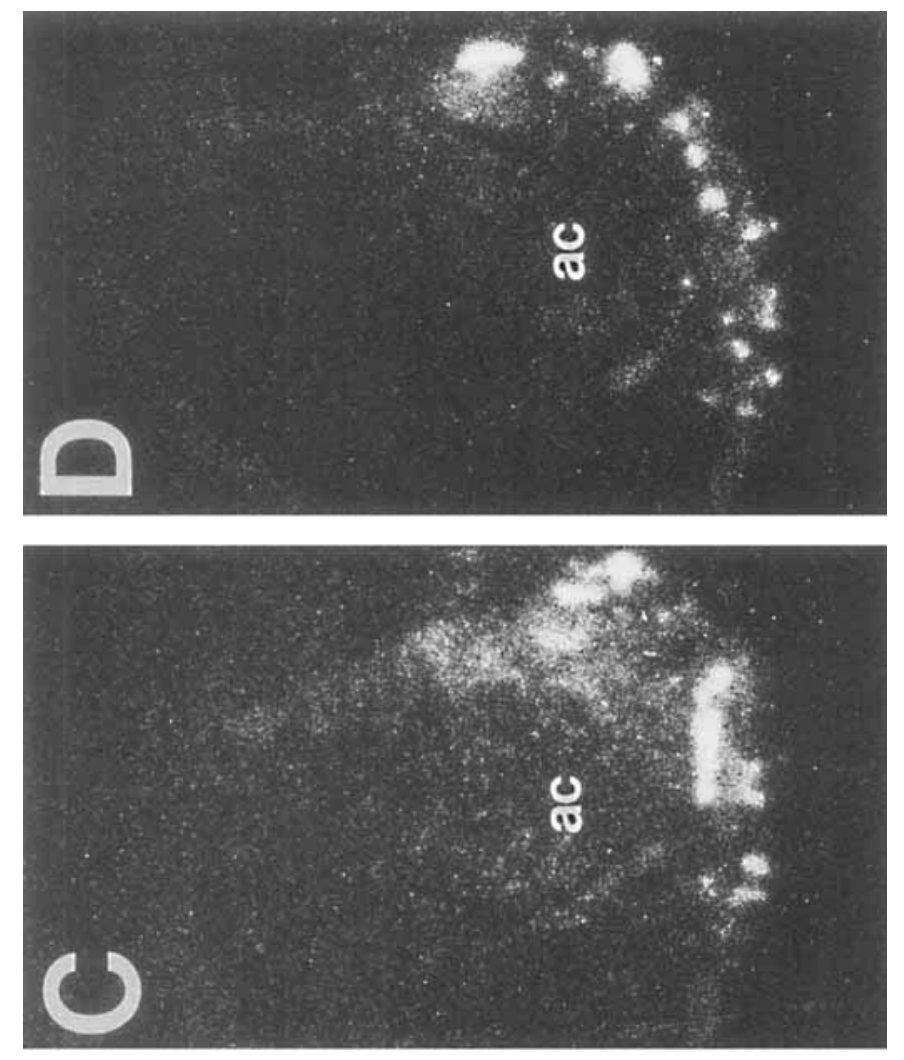

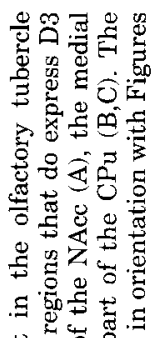

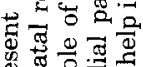

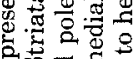
का ता है 他

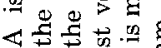
记。

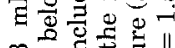
ค๊ s. ํㅠㅇำ

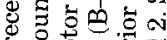

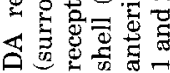
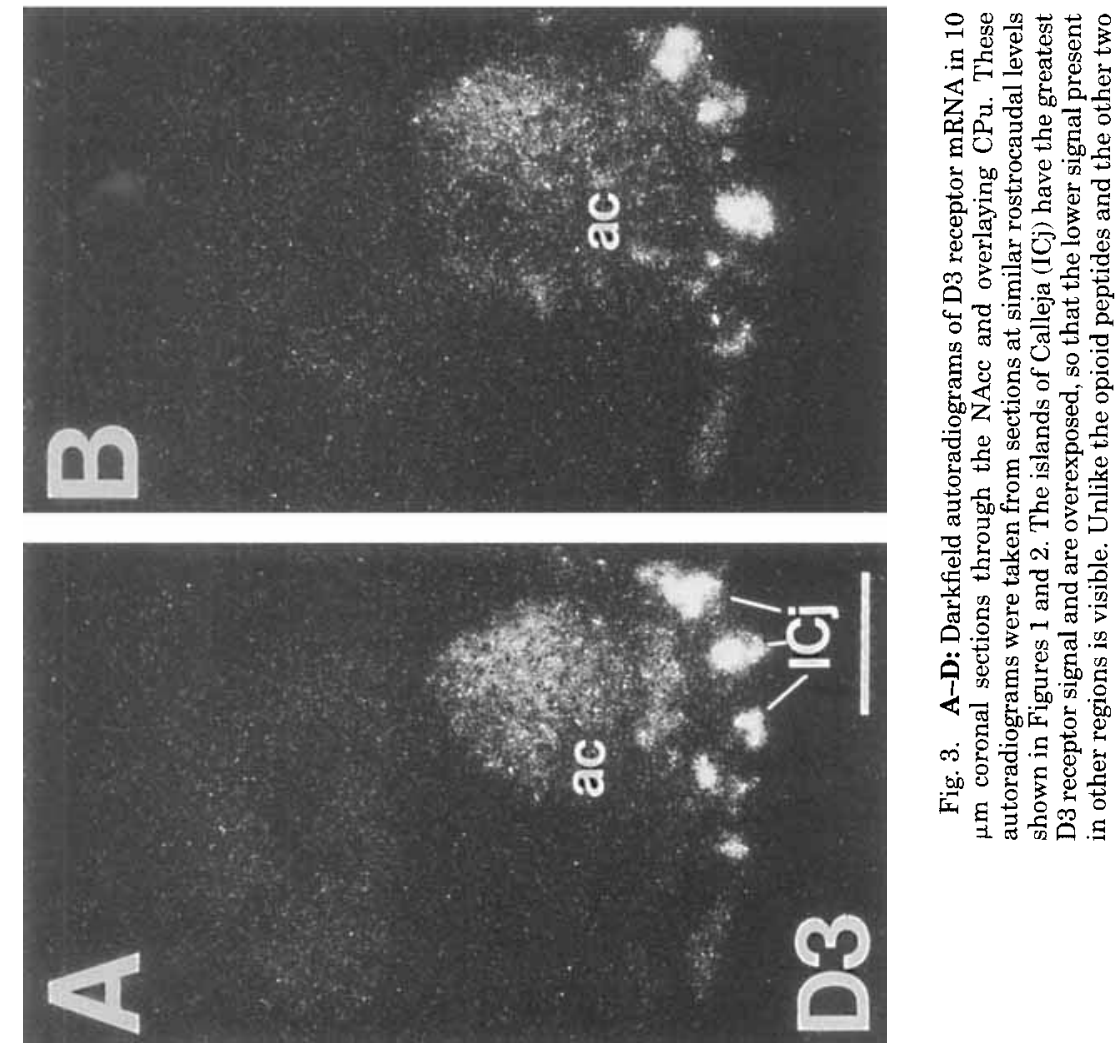

눙

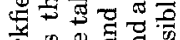

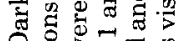

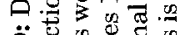
I \% य函

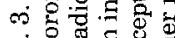
bi 

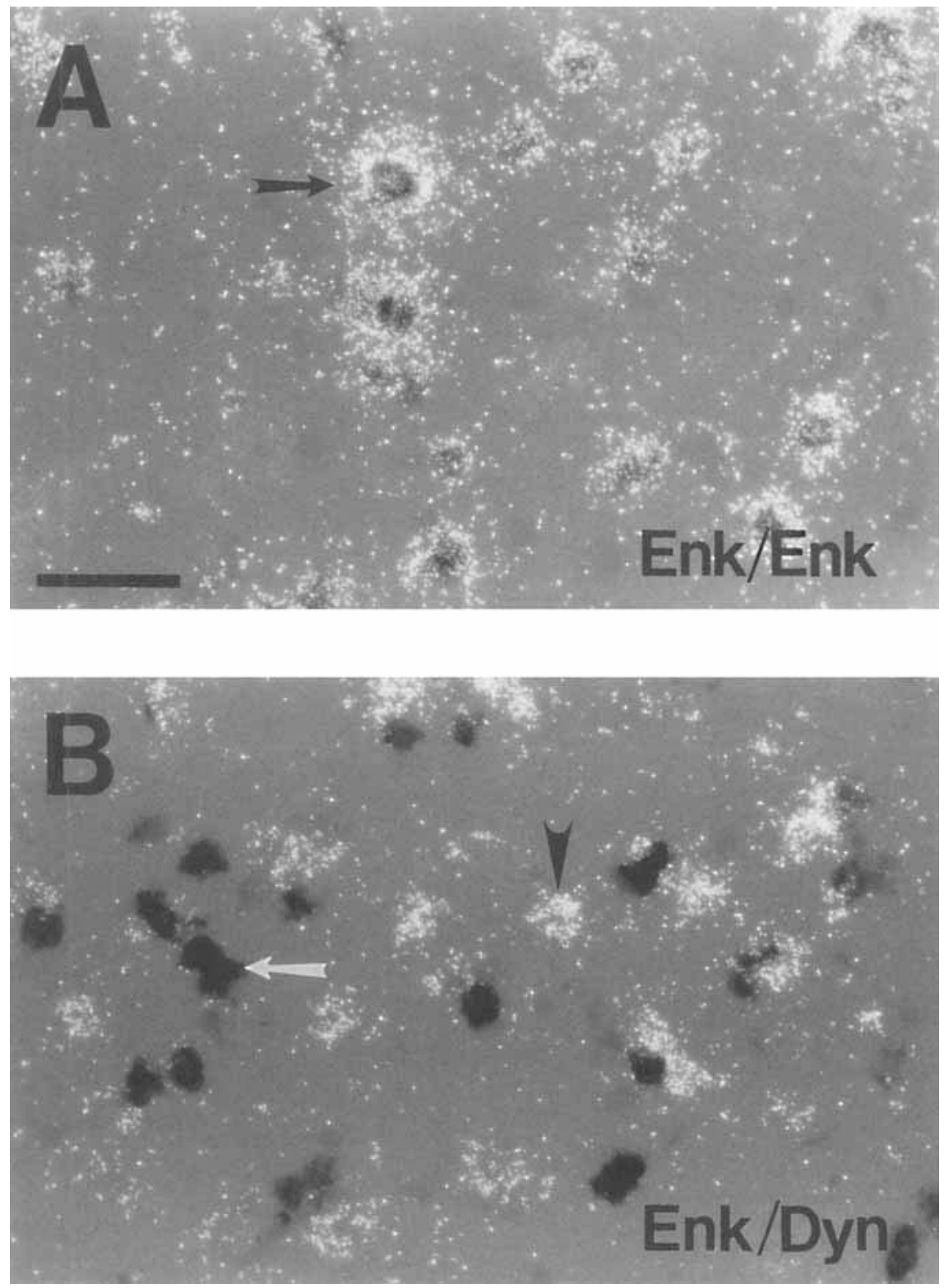

Fig. 4. Photomicrographs of double in situ hybridization experiments using dual film exposures to view both the nonradioactive (brightfield; dark cells) and the radioactive (darkfield; silver grains) signals. A: Cells within the CPu of a control section that was hybridized with both a digoxigenin (dig)-labeled proenkephalin probe and a ${ }^{35}$ S-labeled proenkephalin probe. All positive cells within the $\mathrm{CPu}$ and

ments was not conclusive, however, due to the low D3 receptor signal intensity in this region.

\section{DISCUSSION}

The present study examined the colocalization patterns of opioid peptide mRNAs and DA receptor mRNAs within the dorsal and ventral striatum of the rat. Comparisons among the rostral pole, core, and shell subterritories of the NAcc as well as between the NAcc and the $C P u$ were conducted to determine whether there are differences across these anatomically distinct regions. In the $\mathrm{CPu}$, three the NAcc showed both the nonradioactive and the radioactive signal. The arrow points to an example of this double labeling. B: Illustration showing that proenkephalin (dark cells; arrow) and prodynorphin (silver grains; arrowhead) mRNAs are primarily in separate cells within the $\mathrm{CPu}$. Scale bar $=50 \mu \mathrm{m}$

distinguishable opioid peptide cell populations were detected based on colocalization of proenkephalin and prodynorphin mRNAs with each other as well as with D1, D2, and D3 receptor mRNAs. The two most abundant and widespread configurations within the $\mathrm{CPu}$ were proenkephalin/D2 and prodynorphin/D1 cells. Additionally, within the ventromedial $\mathrm{CPu}$, a subpopulation of prodynorphin cells expresses D3 receptor mRNA, suggesting that a prodynorphin/D1/D3 configuration exists in this subregion of the $\mathrm{CPu}$. Within the NAcc, on the other hand, four distinguishable opioid peptide/DA receptor configurations were detected. The two most prevalent populations seen in the 


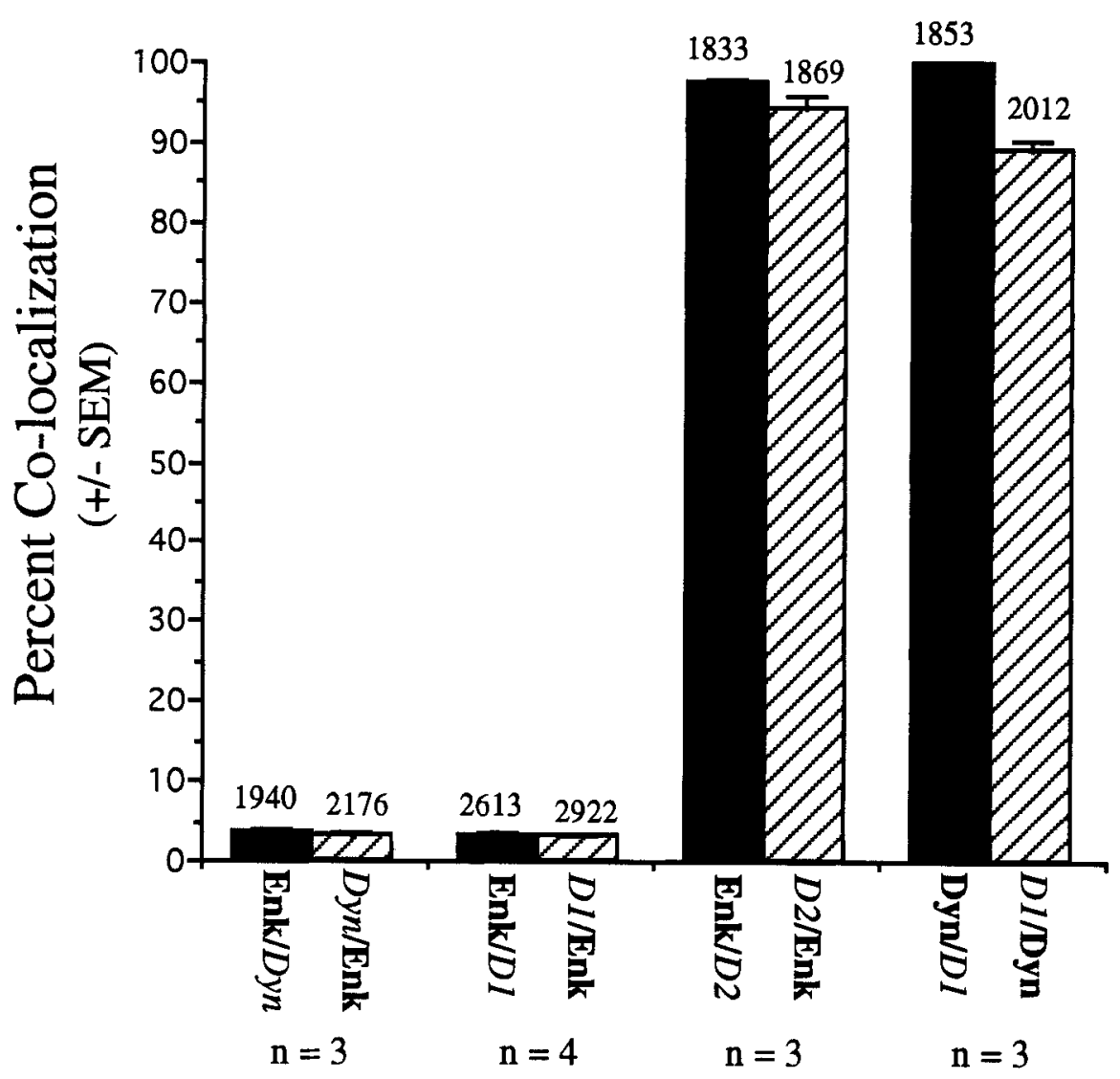

Fig. 5. Bar graph illustrating the percentage of colocalization between proenkephalin (Enk), prodynorphin (Dyn), D1 receptor, and D2 receptor mRNAs. Solid bars represent the percentage of dig-labeled cells (mRNA in boldface) that were also labeled by ${ }^{35} \mathrm{~S}$ (mRNA in italics). Conversely, hatched bars represent the percentage of ${ }^{35} \mathrm{~S}$-labeled cells in the same samples that were also labeled by dig. The numbers above each bar represent the actual number of dig-labeled (solid bars) or ${ }^{35} \mathrm{~S}$-labeled (hatched bars) cells counted. The CPu and the NAcc were divided into subregions at four rostrocaudal levels, and representative cells were counted in each of these regions on both sides of the brain (see Materials and Methods). No regional or rostrocaudal differences were noted in the three or four animals that were used for each combination of counts. Therefore, the numbers generated from cell counts within the $\mathrm{CPu}$ and the NAcc were combined to produce the estimates of colocalization for a particular animal. It should be noted that the cell counts within the NAcc avoided the proenkephalin/ prodynorphin/D1 cell clusters (see text). The data for colocalization between $\mathrm{D} 2$ receptor and prodynorphin mRNA are not shown, because these two mRNAs did not colocalize at any time.
Fig. 6. A-I: Photomicrographs of double in situ hybridization experiments illustrating opioid peptide/DA receptor or opioid peptide/ opioid peptide mRNA expression patterns in the $\mathrm{CPu}$ and the NAcc. The photomicrographs were generated using dual film exposures on color slide film to view simultaneously the nonradioactive (brightfield) and the radioactive (darkfield) signals. To add contrast, the darkfield exposure was taken with a green filter. The color slides were then digitally scanned onto a Kodak photo CD using a Kodak PCD Film Scanner 2000. The scanned images were imported into Adobe Photoshop (version 2.5.1), where they were grouped together; the borders were cropped, and the panels were labeled. Images were adjusted for color balance to produce a uniform tone across panels. In all panels, the dig-labeled probe (purple cells) is listed first, and the radioactive probe (green grains) is listed second. The pink arrows indicate double-labeled cells, the white arrows indicate single dig-labeled cells, and the black arrows indicate single ${ }^{35} \mathrm{~S}$-labeled cells. $\mathrm{A}, \mathrm{B}, \mathrm{D}$, and $\mathrm{E}$ are from the $\mathrm{CPu}$, whereas C, F, G, H, and I are from the NAcc. See Figure 7 for a diagram illustrating the approximate level, region, and orientation of each panel A illustrates that the majority of proenkephalin-positive cells within the $\mathrm{CPu}$ do not express $\mathrm{D} 1$ receptor $\mathrm{mRNA}$. In contrast, as shown in $\mathrm{B}$, the majority of proenkephalin-positive cells within the CPu do express D2 receptor mRNA. Small numbers of D2-positive cells do not express proenkephalin mRNA (black arrow in B). All observable prodynorphinpositive cells within the $\mathrm{CPu}$, as opposed to proenkephalin, expressed $D 1$ receptor mRNA (D), but none of these cells expressed D2 receptor mRNA (E). D3 receptor mRNA expression by proenkephalin (C) and prodynorphin (F) cells was examined in the rostral pole, medial shell, and ventromedial $\mathrm{CPu} . \mathrm{C}$ and $\mathrm{F}$ are from the medial shell (see Fig. 7) but represent the other two regions as well. Analyses of the observable D3-positive cells suggest that proenkephalin and D3 mRNAs are not colocalized (C), whereas a large number of the D3-positive cells do express prodynorphin mRNA (F). The $\mathrm{CPu}$-like proenkephalin/D2 and prodynorphin/D1 expression patterns are also detected within the NAcc. However, embedded in this background, clusters of cells within the rostral pole and the shell exist that coexpress proenkephalin, prodynorphin, and D1 receptor mRNAs, but they are devoid of D2 receptor mRNA. The lower left corners in G-I illustrate this expression pattern in a cluster located along the lateral edge of the NAcc (see Fig. 7). Notice that the cells outside this cluster (top portion in G-1) express a CPu-like pattern. Scale bar $=50 \mu \mathrm{m}$. 

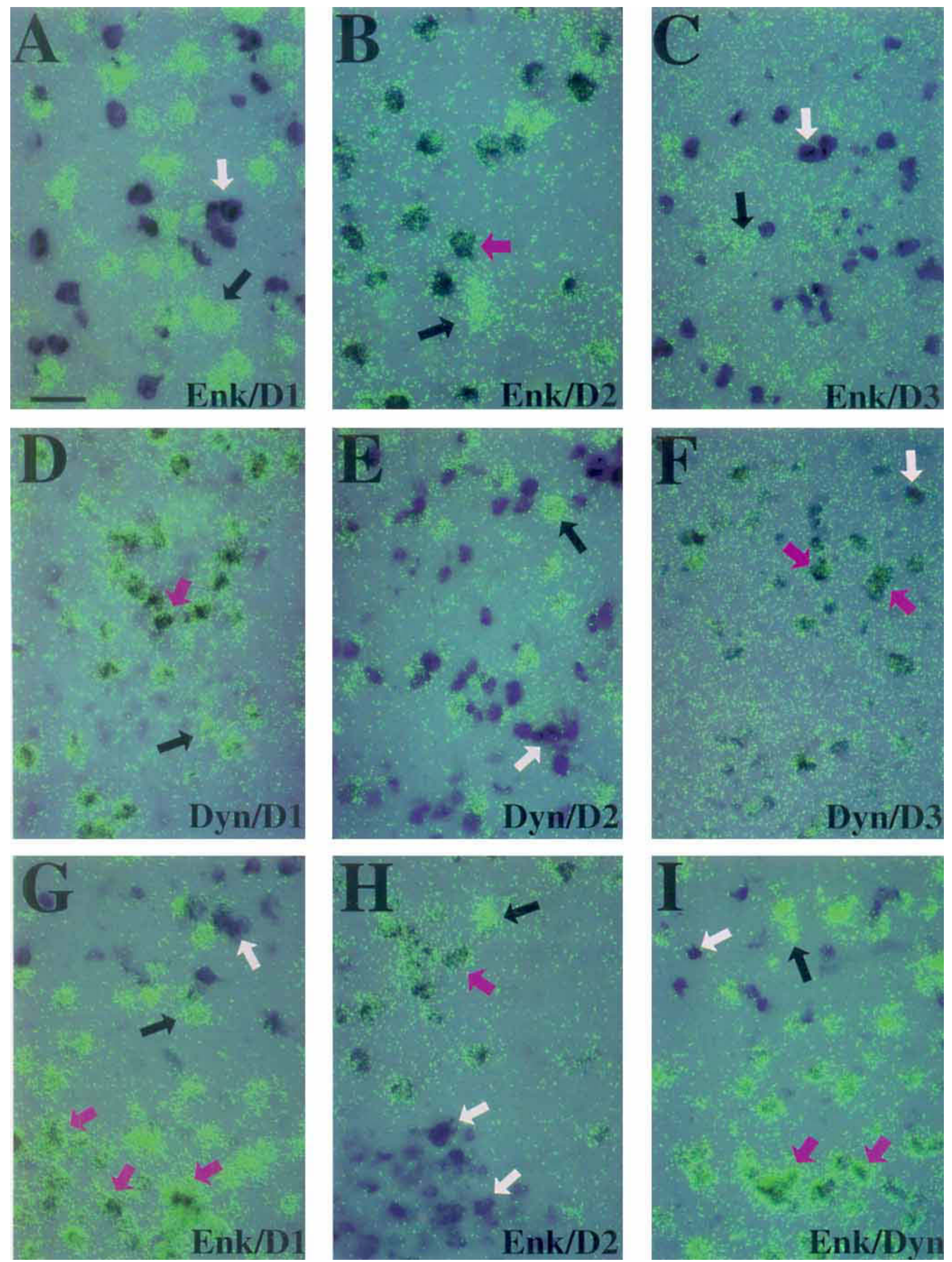


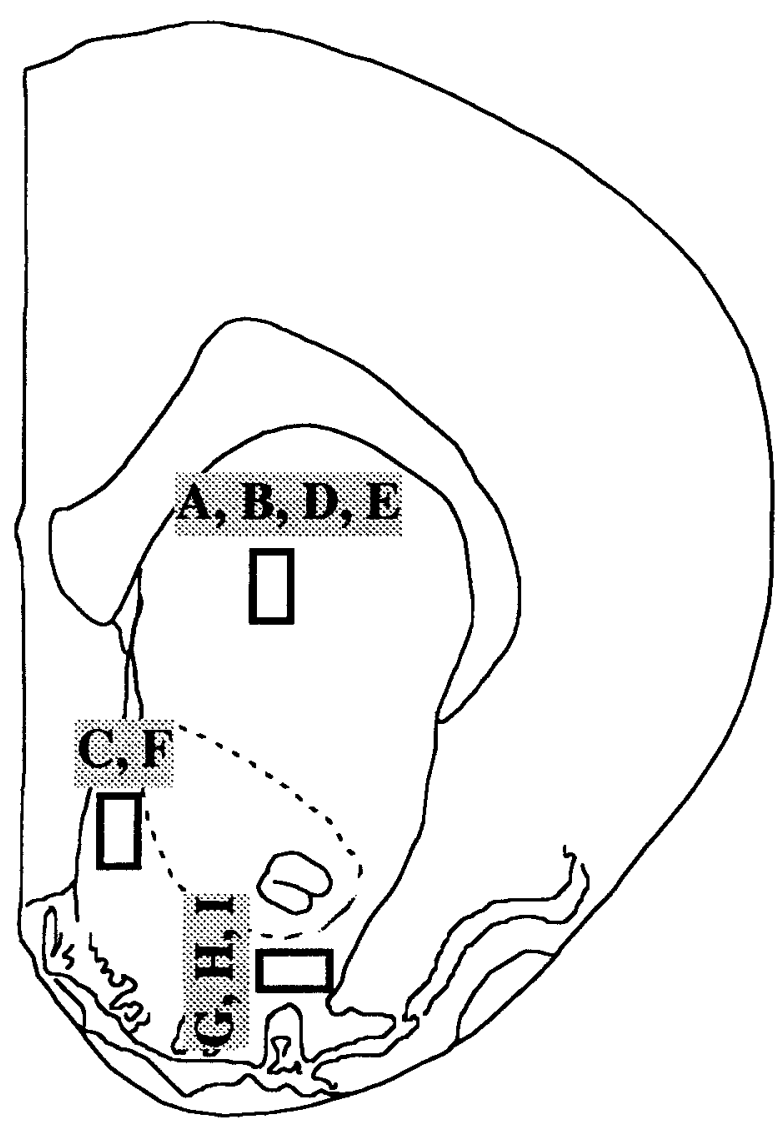

Fig. 7. Diagram illustrating the approximate level, striatal region, and orientation (A-I are positioned at the top) corresponding to the photomicrographs in Figure 6A-I.

rostral pole, core, and shell subdivisions of the NAcc were proenkephalin/D2 and prodynorphin/D1 cells. Additionally, tightly packed clusters of proenkephalin/prodynorphin/D1 cells were detected in the ventral rostral pole and dispersed through the shell. Similar proenkephalin/ prodynorphin/D1 cell clusters were not detected within the $\mathrm{CPu}$, suggesting that these structures are unique to the NAcc. Finally, as with the ventromedial CPu, prodynorphin/ D1/D3 cells were found in the rostral pole and medial shell of the NAcc.

\section{Opioid peptide/DA receptor colocalization}

Comparisons between the $\mathrm{CPu}$ and the NAcc indicate that these two nuclei share some opioid peptide/DA receptor colocalization combinations. All of the prodynorphin cells in the $\mathrm{CPu}$ were observed to express D1 receptor mRNA, but none expressed D2 receptor mRNA. Conversely, the majority of the proenkephalin cells within the $\mathrm{CPu}$ expressed D2 receptor mRNA, whereas only a few isolated proenkephalin cells expressed D1 receptor mRNA. Proenkephalin and prodynorphin cells in the core of the NAcc and in regions of the rostral pole and shell surrounding the proenkephalin/prodynorphin/D1 cell clusters also expressed these colocalization patterns.

D3 receptor mRNA was present in the NAcc and the $\mathrm{CPu}$, but its signal intensity was much lower, and it had a restricted distribution compared to D1 receptor and D2 receptor mRNA. The highest level of D3 receptor mRNA expression was observed within the islands of Calleja, structures that do not express either opioid peptide mRNA. The rostral pole and the shell of the NAcc as well as the most ventromedial portion of the $\mathrm{CPu}$ also expressed D3 receptor signal. The low signal intensity for some of these regions made it difficult to determine whether there was colocalization with the opioid peptide mRNAs. However, clear groups of D3-positive cells were visible within the medial rostral pole, medial shell, and ventromedial $\mathrm{CPu}$. Many of these D3-positive cells expressed prodynorphin mRNA, but none expressed proenkephalin mRNA. Together with the prodynorphin/D1 data, the D3 receptor data suggest that a subpopulation of prodynorphin cells within the medial NAcc and the ventromedial CPu expresses D1 receptor and D3 receptor mRNAs. Anatomical analysis of the ventromedial $\mathrm{CPu}$ has led Heimer and his colleagues (1982) to associate this region more closely with the ventral striatum (i.e., the NAcc and the olfactory tubercle) rather than with the rest of the $\mathrm{CPu}$. Furthermore, a comparison of the afferents and efferents for the regions that express prodynorphin/D1/D3 cells to regions that do not suggests that the prodynorphin/D1/D3 cells are associated with limbic regions of the ventral striatum (Groenewegen et al., 1991; Heimer et al., 1991; Zahm and Brog, 1992).

Previous studies have reported the differential expression of $D 1$ receptor and $D 2$ receptor $m R N A$ s by the opioid peptide cells of the CPu (Gerfen et al., 1990; Le Moine et al., 1990,1991 ), and this has led to the conclusion that these two receptors are generally in separate cell populations within the striatum. This hypothesis, however, does not correlate with the electrophysiological and antisense RNA amplification data of Surmeier and his colleagues (Surmeier et al., 1992, 1993). These studies suggest that the majority of the striatal projection neurons contain both D1 and D2 receptors. Taken together, analyses of D1 and D2 receptor colocalization have produced estimates ranging from approximately $15 \%$ to virtually complete colocalization (Gerfen et al., 1990; Le Moine et al., 1990, 1991; Meador-Woodruff et al., 1991; Ariano et al., 1992; Gerfen, 1992; Surmeier et al., 1992, 1993; Lester et al., 1993). The different percentages appear to depend on the technique used to determine colocalization as well as the definition of the cell populations under investigation. Although the present study did not directly address this issue, the data are consistent with the possible existence of a small percentage of cells expressing D1 receptor and D2 receptor $m R N A s$. For example, although all prodynorphin cells observed in our study expressed D1 receptor mRNA, not all D1-positive cells expressed prodynorphin mRNA. Furthermore, not all D2-positive cells expressed proenkephalin mRNA. Any proportion of these cells theoretically could express D1 receptor and D2 receptor mRNAs. The present study also provides evidence for the coexpression of D1 receptor and D3 receptor mRNAs by a subset of prodynorphin cells, indicating that D1- and D2-like receptor families are colocalized in some cells within the ventral striatum.

It is possible that low levels of mRNA were not detected in the present study. This would suggest that we are underestimating the amount of colocalization between each DA receptor and each opioid peptide mRNA. Especially relevant to the above-mentioned controversy is the distribution of the D1, D2, and D3 receptor mRNAs. However, comparisons of binding and/or immunohistochemical distributions for these substances and our mRNA distributions 


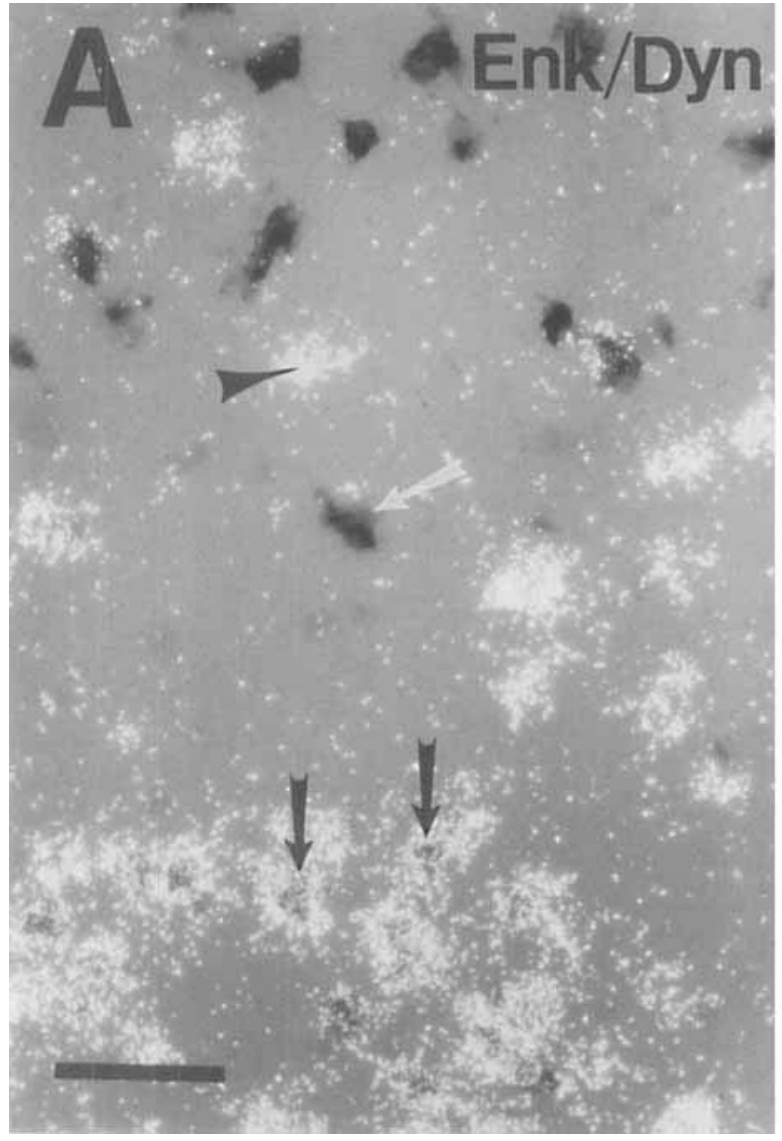

Fig. 8. A double in situ hybridization experiment in adjacent sections comparing the colocalization patterns of prodynorphin (silver grains) and proenkephalin (dark cells) mRNAs (A) to those of D2 receptor (silver grains) and proenkephalin (dark cells) mRNAs (B) within the rostral pole of the NAcc. A and B illustrate the border between a large ventral cluster of proenkephalin cells (bottom) that have a unique expression pattern compared to surrounding regions, which express the typical CPu-like pattern (Fig. 10B shows a lowmagnification photomicrograph of this cluster). proenkephalin cells

suggest that we are probably seeing most of the striatal cells that express these DA receptors. To date, no immunohistochemical data are available for the D3 receptor, but D3 binding sites defined by 7-OH-DPAT and 7-trans-OHPIPAT correspond with the distribution of D3 mRNA we report here (Levesque et al., 1992; Murray et al., 1992; McGonigle et al., 1993). Immunohistochemical and binding analyses of $\mathrm{D} 1$ and $\mathrm{D} 2$ receptors within the NAcc and $\mathrm{CPu}$ also show a high level of correspondence with the distribution of the D1 and D2 receptor mRNAs observed in the present study (Mansour et al., 1990, 1991; Levey et al., 1993).

\section{Proenkephalin/prodynorphin/D1 cell clusters}

The anterior NAcc contained a large cluster of proenkephalin/prodynorphin/D1 cells within the ventral rostral pole. This large cluster separated into smaller cell aggregates in more caudal sections. In the more caudal sections, proenkephalin/prodynorphin/D1 cells aggregated along the lateral edge of the NAcc, within the core/shell border region, and along the medial and ventral border of the NAcc

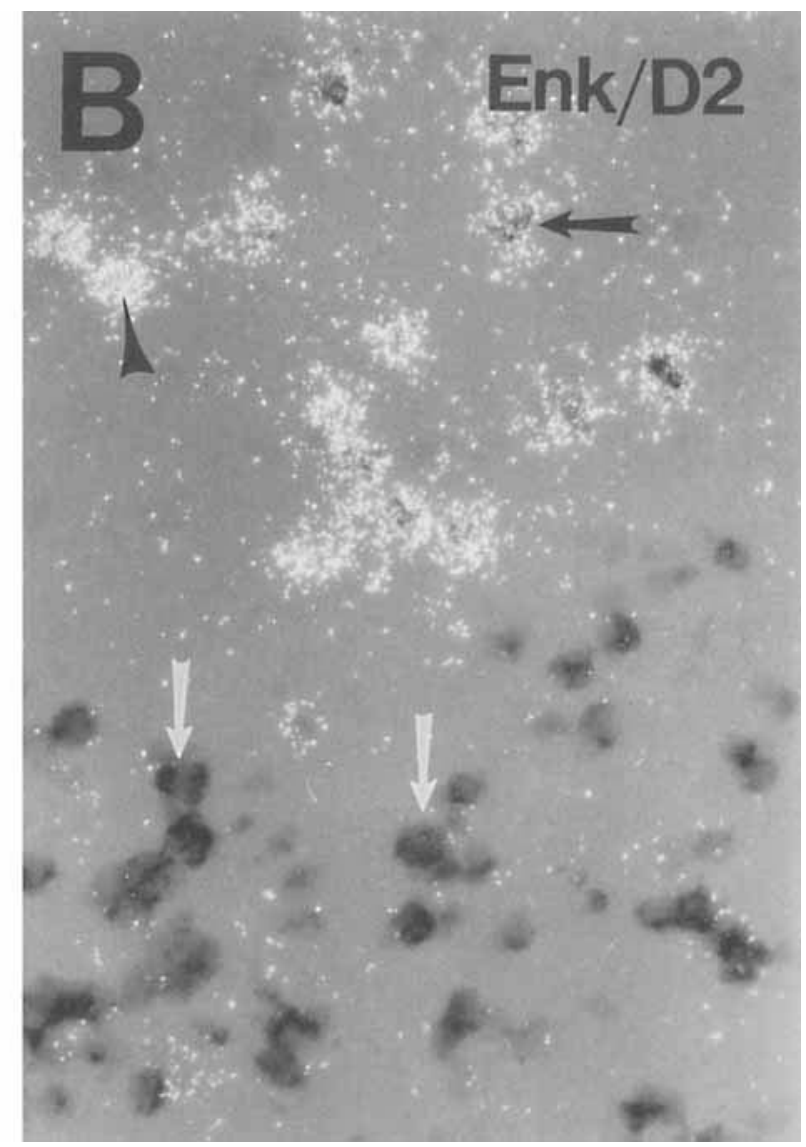

within the ventral cluster express prodynorphin mRNA (A, black arrows) but do not express D2 receptor mRNA (B, white arrows). Outside this cluster, proenkephalin (A, white arrow) and prodynorphin (A, arrowhead) mRNAs are in separate cells, whereas proenkephalin and D2 receptor mRNAs are colocalized (B, black arrow). In the transition area between the cluster and the noncluster region, there are a number of D2-positive cells that do not express proenkephalin mRNA (B, arrowhead). Scale bar $=50 \mu \mathrm{m}$.

in proximity to the islands of Calleja. Interestingly, unlike the colocalization of proenkephalin and $D 2$ receptor mRNAs seen in surrounding regions, D2 receptor mRNA was not expressed by proenkephalin cells within these clusters. The results from the single in situ hybridization experiments indicated that these proenkephalin/prodynorphin/D1 cells can be observed within Nissl-stained material as clusters of more densely packed cells compared to surrounding regions. The present data suggest, therefore, that the proenkephalin/prodynorphin/D1 cell clusters correspond, at least in part, to clusters of cells previously described by Herkenham and his colleagues (1984). In their experiments, Nisslstained sections through the NAcc were found to contain clusters of densely packed cells located in the ventral rostral pole, along the lateral edge, within the medial and ventral shell, and along the core/shell border region. However, these investigators (Herkenham et al., 1984) reported several clusters in more central and dorsal areas of the NAcc, where we did not see corresponding proenkephalin/ prodynorphin/D1 clusters. Therefore, it appears that the 

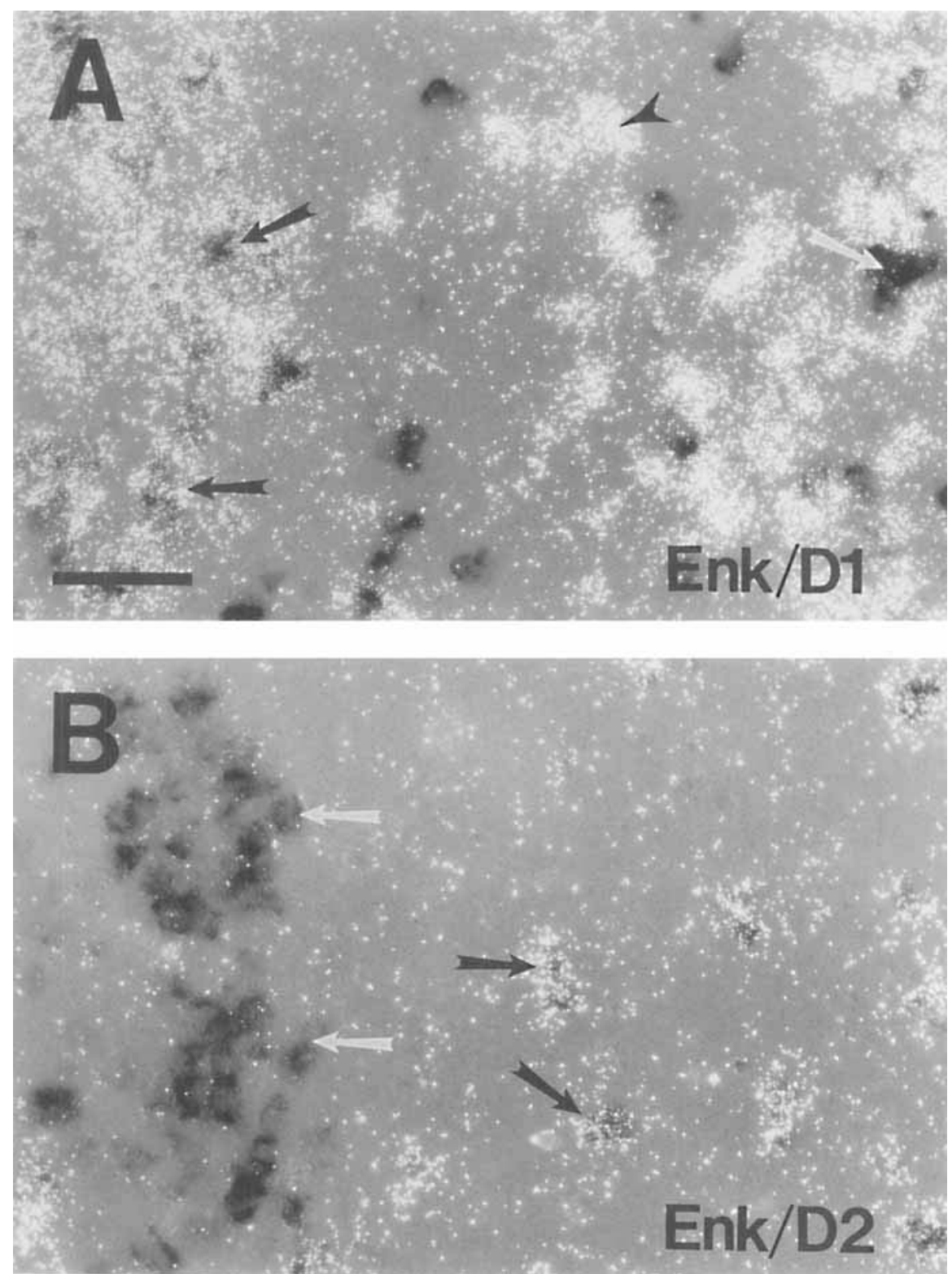

Fig. 9. A double in situ hybridization experiment comparing the colocalization pattern of proenkephalin mRNA (dark cells) with D1 receptor (silver grains; A) or D2 receptor (silver grains; B) mRNAs. A and B show a cluster located in the medial shell of the NAcc (left is medial; Fig. 10D shows a low-magnification photomicrograph of this cluster). On the left in both A and B, there is a cluster of proenkephalin cells that express D1 receptor mRNA (A, black arrows) but do not express D2 receptor mRNA (B, white arrows). Outside the cluster, proenkephalin (A, white arrows) and D1 receptor (A, black arrowhead) mRNAs are in separate cells, whereas proenkephalin and D2 receptor mRNAs are colocalized (B, black arrow).
Fig. 10. A-E: Distribution of proenkephalin/prodynorphin/D1 cell clusters within the NAcc. A illustrates where these clusters were observed in six animals at four rostrocaudal levels. Low-magnification photomicrographs of representative sections at the levels in $\mathrm{A}$ are shown in B-E, which illustrate the distribution of a dig-labeled proenkephalin probe (dark cells) in double in situ hybridization experiments. Adjacent sections were used to analyze the colocalization of the dig-labeled proenkephalin probe with ${ }^{35}$ S-labeled prodynorphin, D1 receptor, or D2 receptor probes. Smaller proenkephalin/prodynor$\mathrm{phin} / \mathrm{D} 1$ cell clusters are marked with arrows, whereas larger clusters are outlined with dashed lines. B: The ventral rostral pole contained a large cluster of cells that coexpressed proenkephalin, prodynorphin, and D1 receptor mRNAs, but these cells were devoid of D2 receptor mRNA. High-magnification photomicrographs of cells at the border of this ventral cluster (8) are shown in Figure 8. C-E: In more caudal sections, this large ventral proenkephalin/prodynorphin/D1 cell cluster separated into smaller clusters that were dispersed through the medial, ventral, and lateral shell subregion of the NAcc [Fig. 9 displays high-magnification photomicrographs of the medial cluster (9) shown in $\mathrm{C}$ ]. ac, Anterior commissure; Tu, olfactory tubercle; $\mathrm{ICj}$, islands of Calleja; ICjM, major island of Calleja. Scale bar $=500 \mu \mathrm{m}$. 
A
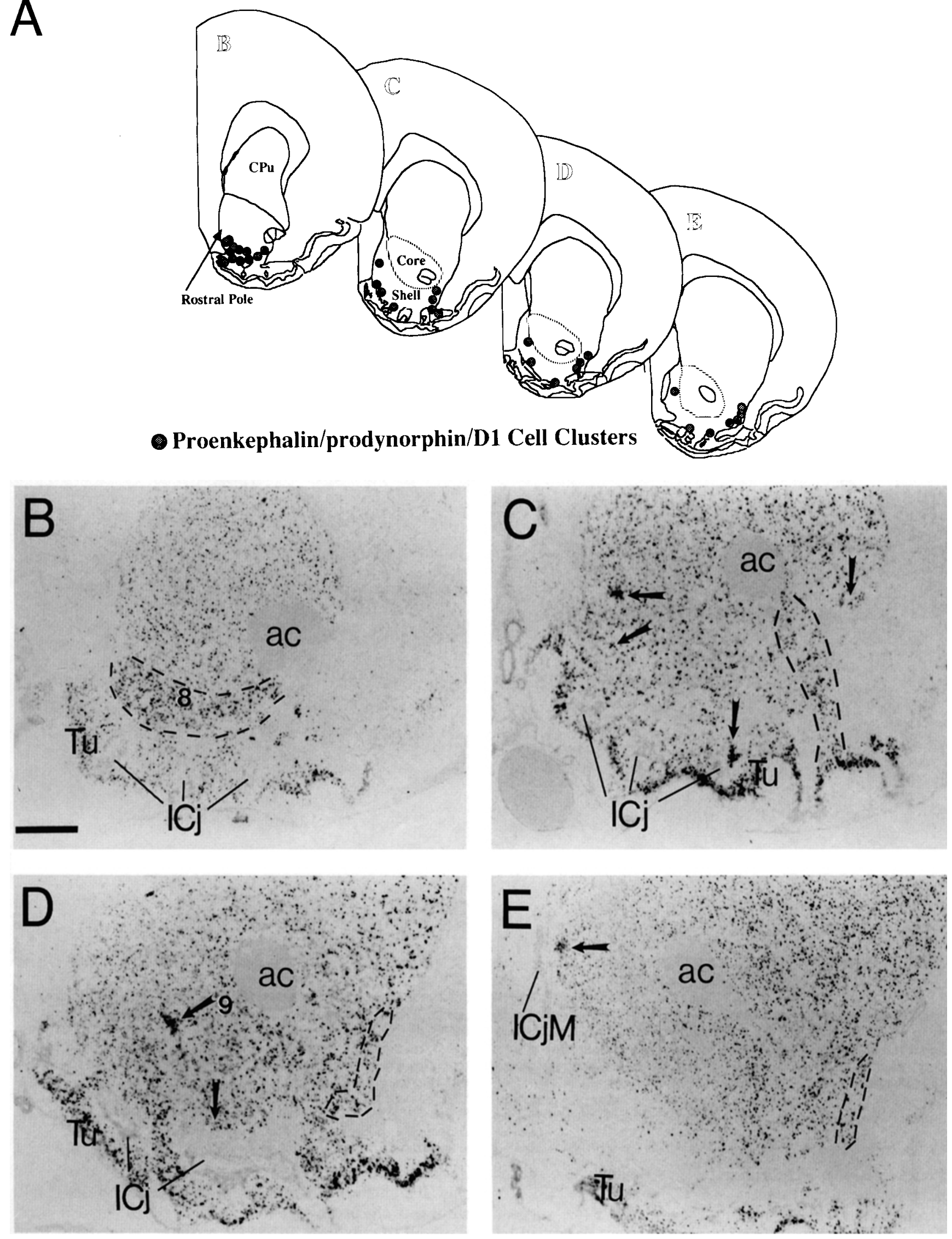

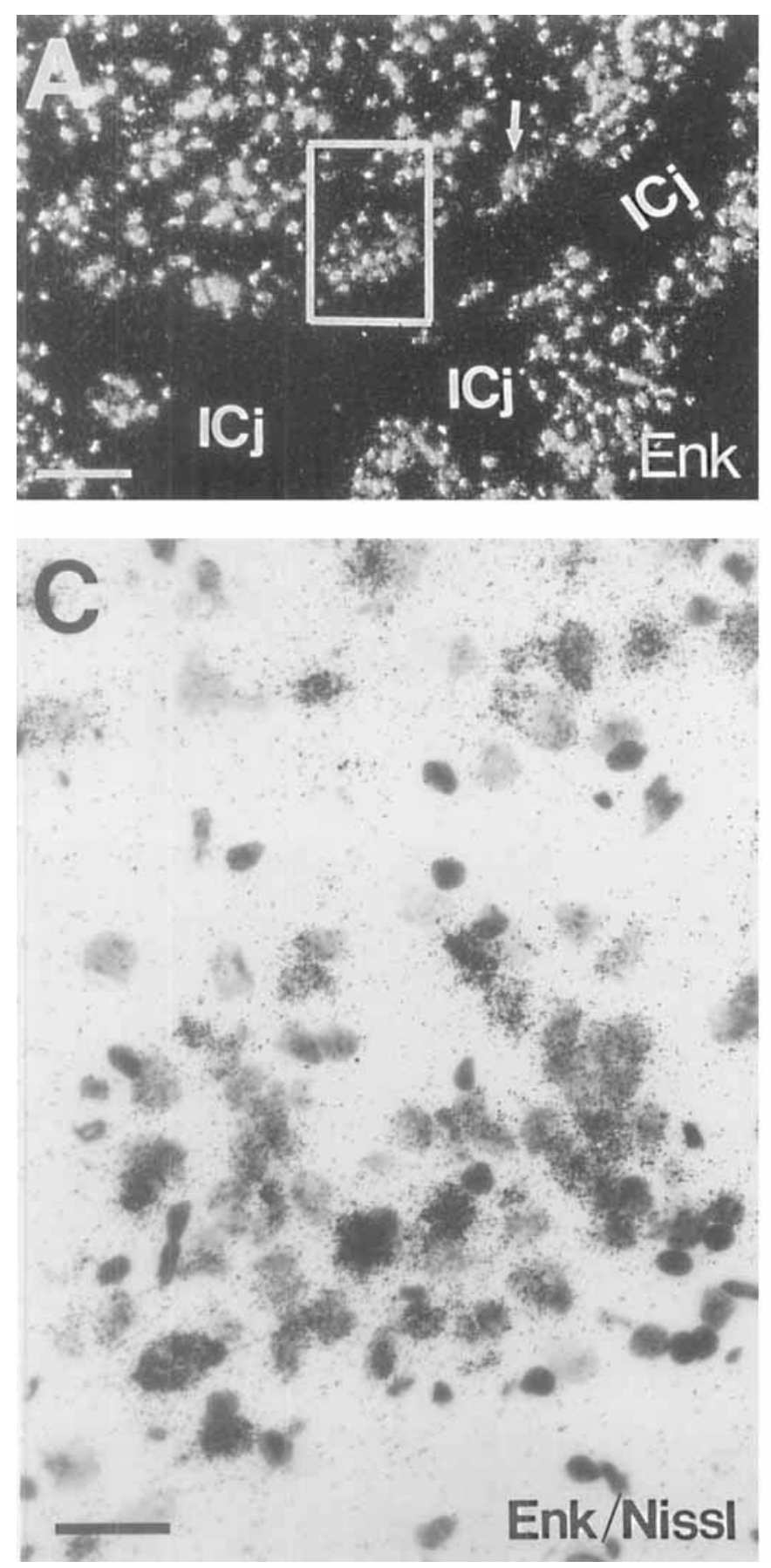

Fig. 11. Darkfield photomicrographs of semiadjacent sections processed for single in situ hybridization with a ${ }^{35} \mathrm{~S}$-labeled proenkephalin probe (A) or a ${ }^{35}$ S-labeled $\mathrm{D} 2$ receptor probe (B). The sections were dipped in emulsion to visualize the silver grains and then stained with cresyl violet. The NAcc contains clusters of cells that express proenkephalin mRNA but not D2 receptor mRNA. Adjacent sections revealed that cells within these clusters did express D1 receptor and prodynorphin mRNAs (data not shown). Two of these proenkephalin cell clusters

proenkephalin/prodynorphin/D1 clusters may be a subset of the Nissl-cell clusters.

Comparisons between the $\mathrm{CPu}$ and the NAcc suggest that, like the compact Nissl-stained clusters described by
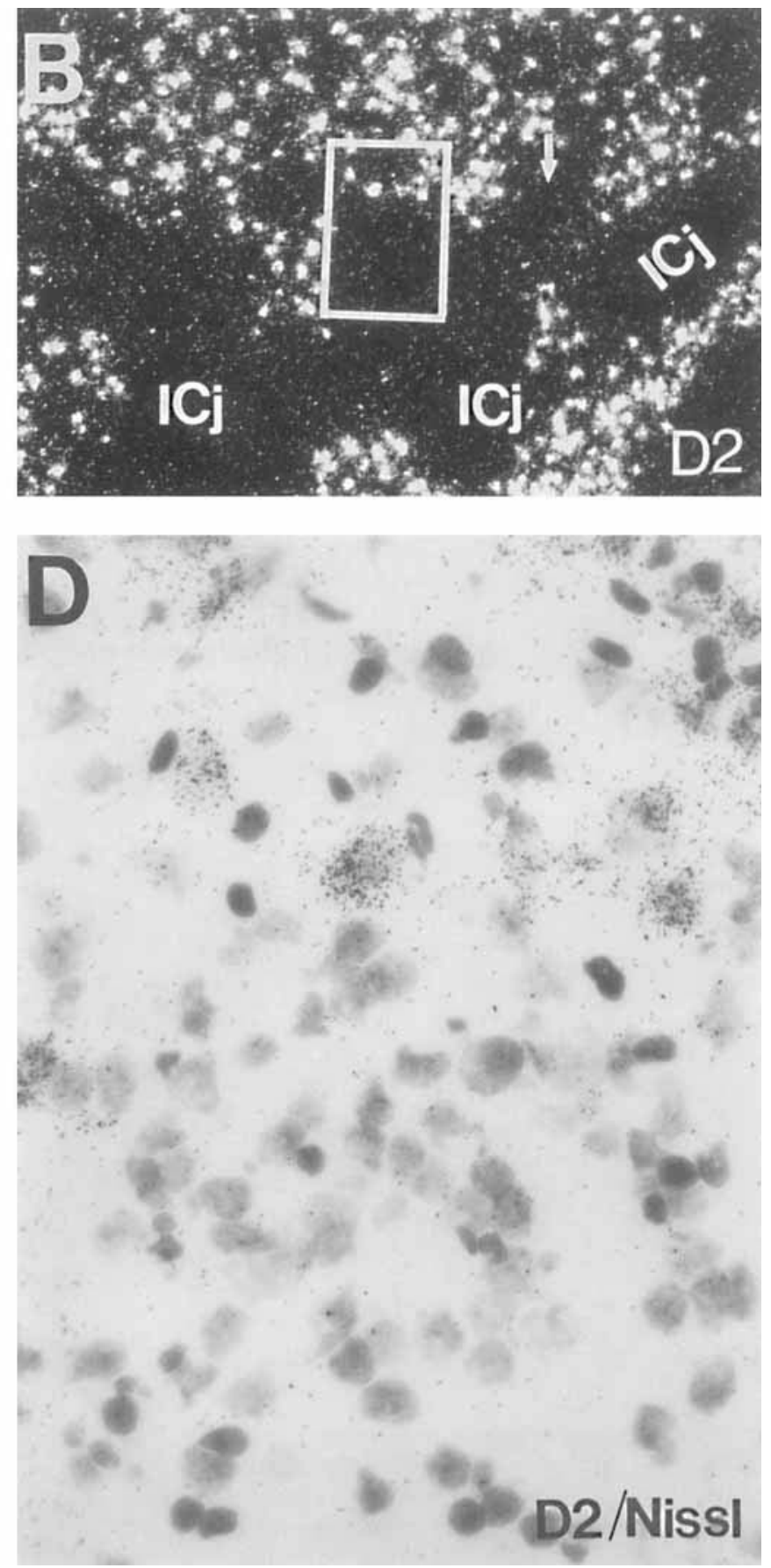

that are in close proximity to the $\mathrm{ICj}$ are shown in $\mathrm{A}$ (white arrow and inset). The corresponding regions in $B$ do not express D2 receptor mRNA. C,D: Higher magnification photomicrographs of the insets in A and $B$, respectively. Note that cells within the cluster contain proenkephalin signal (C), but they are devoid of D2 receptor signal (D). Also note that the cells within this cluster (bottom) are more densely packed than the cells outside the cluster (C,D, top). Scale bars $=150 \mu \mathrm{m}$ in A,B, $30 \mu \mathrm{m}$ in C,D.

Herkenham et al. (1984), the proenkephalin/prodynorphin/D1 clusters are not present in the CPu. A small number of the proenkephalin-positive cells in the $\mathrm{CPu}$ were observed to coexpress either D1 receptor or prodynorphin 
mRNAs. However, these isolated cells were rare and were scattered through the nucleus, making it difficult to determine whether all three mRNAs were expressed in the same cells. These findings suggest that it is feasible that there are a few proenkephalin/prodynorphin/D1 cells within the $\mathrm{CPu}$, but, if they exist, they are rare and they do not aggregate together as is seen in the NAcc.

Studies examining the immunoreactivity or receptor binding patterns for a number of neuroactive substances in the NAcc have reported complex relationships with the Nissl-cell clusters (Herkenham et al., 1984; Zahm and Heimer, 1988; Voorn et al., 1989; Zahm and Brog, 1992; Jongen-Relo et al., 1993). Herkenham et al. (1984) found that the densely packed cells in Nissl-stained material corresponded extensively with ${ }^{3} \mathrm{H}$-naloxone binding as well as with areas of weak acetylcholinesterase (AChE) staining. Voorn et al. (1989) reported that cell clusters in the shell and its border coincide with zones of weak enkephalin, substance P, and DA immunoreactivity. On the other hand, analysis of substance $P$ immunoreactivity (Zahm and Heimer, 1988; Zahm and Brog, 1992) through the rostrocaudal extent of the NAcc revealed that there is a large cluster of tightly packed cells within the basal parts of the rostral pole that exhibits dense substance P immunoreactivity. Appendages of this immunohistochemically distinct district extend into rostral parts of the olfactory tubercle and laterally into an adjoining densely substance P-immunoreactive lamina, called the lateral stripe (Zahm and Heimer, 1988; Zahm and Brog, 1992). Comparisons of the basal cluster and the lateral stripe with ${ }^{3} \mathrm{H}$-naloxone binding and areas of weak AChE staining show significant overlap (Zahm and Brog, 1992), suggesting that these substance P-rich areas coincide with the Nissl-cell clusters. However, as noted above, smaller clusters that exhibit weak immunoreactivity for substance P, enkephalin, and DA within the medial shell and the core/shell border region also correspond to opiate receptor-rich and $\mathrm{AChE}$-poor clusters, suggesting that there may be neurochemically distinct subsets of the Nissl-cell clusters (Zahm and Heimer, 1988; Voorn et al., 1989; Zahm and Brog, 1992). Overlaying the distribution of the proenkephalin/prodynorphin/D1 cell clusters with the immunohistochemically distinct clusters described above reveals an additional level to the heterogeneity of the Nissl-cell clusters. First, like the substance P-rich zones, the proenkephalin/prodynorphin/D1 clusters are seen in the basal portion of the rostral pole as well as the lateral stripe. However, proenkephalin/prodynorphin/D1 clusters were also found in close association with the islands of Calleja in the ventral and medial NAcc as well as along the core/shell border, suggesting that these proenkephalin/prodynorphin/D1 cells may correspond, at least in part, to the substance P-poor clusters described by Voorn et al. (1989).

The absence of D2 receptor mRNA in the proenkephalin/ prodynorphin/D1 clusters was quite striking. Immunohistochemical (Levey et al., 1993) and binding (Berendse and Richfield, 1993) analyses of $D 1$ and $D 2$ receptors within the NAcc by other investigators suggest that this differential distribution may also occur in other species. In a recent study by Levey et al. (1993), the immunoreactivity patterns for $\mathrm{D} 1$ and $\mathrm{D} 2$ receptor proteins were expressed in distinct heterogeneous patterns within the NAcc of the rat, monkey, and human brain. The patterns described for the D1 and D2 receptor proteins in the NAcc by these authors correspond to some extent with distributions we see for the mRNAs. In another study examining the relationship of D1 and D2 receptor binding in the NAcc of human brain, Berendse and Richfield (1993) found that areas of high D1 binding and low D2 binding in caudal sections overlapped with areas of high cell density. Although it is not clear whether these regions are analogous to the cell clusters observed in rat, it will be interesting for future studies to examine opioid/DA colocalization patterns in primate tissue.

\section{NAcc circuitry}

Comparisons of the efferents of the rostral pole, shell, and core regions reveal that the core projects robustly to conventional basal ganglia circuitry through the dorsolateral VP as well as the entopeduncular nucleus (Heimer et al., 1991). Efferents of the shell and portions of the rostral pole, on the other hand, bypass these regions and terminate in the ventromedial VP and nontraditional areas, including parts of the bed nucleus of the stria terminalis, the lateral preoptic region, the sublenticular substantia innominata, and the entire length of the lateral hypothalamus (Zahm and Heimer, 1990; Heimer et al., 1991; Zahm and Brog, 1992). These projection patterns have led Alheid and Heimer (Alheid and Heimer, 1988; Heimer and Alheid, 1991) to postulate that the shell of the NAcc consists of both traditional striatal-like characteristics as well as attributes of the extended amygdala. Analysis of NAcc afferents indicates a general topographic order that generally obeys core/shell boundaries, but the shell has an additional suborganization, where some of the shell afferents appear to avoid and others to innervate preferentially the Nissl-cell clusters (Groenewegen et al., 1991; Zahm and Brog, 1992). A number of thalamic inputs, including anterior and posterior paraventricular, paratenial, and central medial nuclei, were found to avoid the Nissl clusters (Herkenham et al., 1984). Analysis of hippocampal and medial frontal cortex input to the clusters suggests that projections from the hippocampus and the ventral subiculum avoid, whereas the ventral and deep dorsal prelimbic areas of the medial prefrontal cortex preferentially innervate, the clusters (Herkenham et al., 1984; Groenewegen et al., 1987; Berendse et al., 1992a). Input from the VTA, on the other hand, has a less pronounced difference (Zahm and Heimer, 1993), but it has been noted that Nissl clusters appear to receive less dense innervation compared to surrounding regions (Herkenham et al., 1984). The efferent targets of the Nissl-cell clusters have not been extensively studied, but there is some evidence that these areas do not project directly to the VTA or the substantia nigra (Berendse et al., $1992 b)$. Other studies involving injections of a retrograde tracer into the VP suggest that the clusters may project to this pallidal region, but it is possible that this study was picking up fibers passing through the VP on their way to the lateral hypothalamus (Zahm and Brog, 1992). The location of the Nissl-cell clusters in apparent transition zones within the NAcc (such as the rostrobasal area and along the medial and lateral edges) plus the finding that the lateral stripe appears to extend caudally into the amygdala with no clear boundaries between this cluster and the intercalated cell islands of the amygdala (Herkenham et al., 1984) suggest that these structures may be relevant to communication with the extended amygdala (Herkenham et al., 1984; Heimer and Alheid, 1991; Zahm and Heimer, 1993). Future studies will, therefore, examine the efferent connections of these cell clusters more fully to help determine how these cells are interrelated to the classical basal 
ganglia circuitry as well as to the extended amygdala circuitry.

\section{DA-opioid interactions in the NAcc}

Behaviorally, DA-opioid interactions within the NAcc have been implicated in the reinforcing properties of two major classes of abused drugs, the psychomotor stimulants and the opiates (for a review, see Cooper, 1991). Analyses of D1- and D2-specific drugs have shown that the two DA receptor families produce distinct effects in reinforcement paradigms. Systemic and intraaccumbens injections of D1 and D2 agonists produce place preferences (White et al., 1991), but only D1 antagonists produce place aversions, whereas D2 antagonists are motivationally neutral (Shippenberg and Herz, 1987; Shippenberg et al., 1991). Furthermore, the positive reinforcing effects of mu-opiate drugs and the negative reinforcing effects of kappa-opiate drugs are preferentially disrupted by D1 antagonists (Shippenberg and Herz, 1988). These data suggest that both D1- and D2-like receptors can access the reward circuitry of the NAcc. There is not a complete overlap, however, because only D1-like receptors can interfere with the positive reinforcing circuits accessed by mu-opiate drugs, and only D1 receptors access circuitry involved in place aversions. Although it must be determined, the localization of mu receptor binding (defined by ${ }^{3} \mathrm{H}$-naloxone) to the Nissl-cell clusters together with our finding that D1 receptors, but not D2 receptors, are present in the proenkephalin/ prodynorphin/D1 subset of these cell clusters suggests that these specializations may be a critical site for D1 and mu-opiate receptor interactions within the NAcc.

Both the psychomotor stimulants and the opiates produce reinforcing effects as well as locomotor effects when injected systemically or directly within the NAcc (Cooper, 1991). Circuitry data suggest that these functions may be processed primarily by different subdivisions of the NAcc. For example, the core projects directly and indirectly to a number of subcortical structures that have been linked to motor behaviors, including the substantia nigra, the entopeduncular nucleus, and the subthalamic nucleus (Groenewegen and Russchen, 1984; Groenewegen et al., 1991; Heimer et al., 1991). The shell, on the other hand, is interconnected with three other brain sites that have been linked to drug reinforcement; the VTA, the lateral hypothalamus, and the medial prefrontal cortex (Groenewegen and Russchen, 1984; Groenewegen et al., 1991; Heimer et al., 1991; Wise and Hoffman, 1992). In the present study, we observed differences in the DA receptor environments between the core and the shell. Two unique opioid peptide/DA receptor expression patterns are seen in the shell; proenkephalin/ prodynorphin/D1 cells and prodynorphin/D1/D3 cells. The core, on the other hand, expresses opioid peptide/DA receptor combinations that are identical to those of the $\mathrm{CPu}$, which has also been associated with motor behaviors. Although they must be examined carefully in future studies, the above-described data suggest that the DA receptor environment observed within the shell may contribute to the processing of drug reinforcement properties within the NAcc.

\section{CONCLUSIONS}

The present study describes prodynorphin/D1, proenkephalin/D2, prodynorphin/D1/D3, and proenkephalin/ prodynorphin/D1 cells within the NAcc. These four cell types are differentially expressed in the rostral pole, the core, and the shell, suggesting that the opioid peptide efferents within the these three subregions of the NAcc have distinct DA receptor environments. Future tracttracing studies focusing on the projection targets of these four opioid peptide/DA receptor cell types may, therefore, help integrate NAcc circuitry data with results from functional studies that have examined opiate-DA interactions within the NAcc.

\section{ACKNOWLEDGMENTS}

The authors thank Drs. Charles Fox and William Cullinan for their insightful discussions concerning these experiments and their critical reading of the manuscript. This work was supported by The Lucille P. Markey Charitable Trust (88-46), NIDA (DA 02265), NIMH (MH 42251), and NIDA (DA 05549; E.J.C.)

\section{LITERATURE CITED}

Alheid, G.F., and L. Heimer (1988) New perspectives in basal forebrain organization of special relevance for neuropsychiatric disorders: The striatopallidal, amygdaloid, and corticopetal components of substantia innominata. Neuroscience 27:1-39.

Anderson, K.D., and A. Reiner (1990) Extensive cooccurrence of substance P and dynorphin in striatal projection neurons: An evolutionarily conserved feature of basal ganglia organization. J. Comp. Neurol. 295:339369.

Ariano, M.A., C.J. Stromski, E.M. Smyk-Randall, and D.R. Sibley (1992) D2 dopamine receptor localization on striatonigral neurons. Neurosci. Lett. 144:215-220.

Bals-Kubik, R., A. Ableitner, A. Herz, and T.S. Shippenberg (1993) Neuroanatomical sites mediating the motivational effects of opioids as mapped by the conditioned place preference paradigm in rats. J. Pharmacol. Exp. Ther. 264:489 495 .

Bardo, M.T., and R.P. Hammer (1991) Autoradioagraphic localization of dopamine $\mathrm{D} 1$ and $\mathrm{D} 2$ receptors in rat nucleus accumbens: Resistance to differential rearing conditions. Neuroscience 45:281-290.

Berendse, H.W., and E.K. Richfield (1993) Heterogeneous distribution of dopamine D1 and D2 receptors in the human ventral striatum. Neurosci. Lett. 150:75-79.

Berendse, H.W., Y. Galis-de Graaf, and H.J. Groenwegen (1992a) Topographical organization and relationship with ventral striata compartments of prefrontal corticostriatal projections in the rat. J. Comp. Neurol. 316:314347.

Berendse, H.W., H.J. Groenewegen, and A.H.M. Lohman (1992b) Compartmental distribution of ventral striatal neurons projecting to the mesencephalon in the rat. J. Neurosci. 12:2079-2103.

Bouthenet, M.L., E. Souil, M.P. Martres, P. Sokoloff, B. Giros, and J.C. Schwartz (1991) Localization of dopamine D3 receptor mRNA in the rat brain using in situ hybridization histochemistry: Comparison with dopamine D2 receptor mRNA. Brain Res. 564:203-219.

Boyson, S.J., P. McGonigle, and P.B. Molinoff (1986) Quantitative autoradiographic localization of the D1 and D2 subtypes of dopamine receptors in rat brain. J. Neurosci. 6:3177-3188.

Brog, J.S., A. Salyapongse, A. Deutch, and D.S. Zahm (1993) The patterns of afferent innervation of the core and shell in the "accumbens" part of the rat ventral striatum: Immunohistochemical detection of retrogradely transported fluoro-gold. J. Comp. Neurol. 338:255-278.

Bunzow, J.R., H.H.M. Van Tol, D.K. Grandy, P. Albert, J. Salon, M. Christie, C.A. Machida, K.A. Neve, and O. Civelli (1988) Cloning and expression of a rat D2 dopamine receptor cDNA. Nature 336:783-787.

Civelli, O., J. Douglass, A. Goldstein, and E. Herbert (1985) Sequence and expression of the rat prodynorphin gene. Proc. Natl. Acad. Sci. USA $82: 4291-4295$

Civelli, O., J.R. Bunzow, D.K. Grandy, Q.-Y. Zhou, and H.H.M. Van Tol (1991) Molecular biology of the dopamine receptors. Eur. J. Pharmacol. 207:277-286.

Cooper, S.J. (1991) Interactions between endogenous opioids and dopamine: Implications for reward and aversion. In P. Willner and J. Scheel-Kruger (eds.): The Mesolimbic Dopamine System: From Motivation to Action. London: John Wiley and Sons, Ltd., pp. 331-366. 
Day, R., M.K.-H. Schafer, M.W. Collard, E. Weihe, and H. Akil (1993) Prodynorphin gene expression in the rat intermediate pituitary lobe: Gender differences and postpartum regulation. Endocrinology 133:26522659.

De Block, M., and D. Debrouwer (1993) RNA-RNA in situ hybridization using digoxigenin-labeled probes: The use of high molecular weight polyvinyl alcohol in the alkaline phosphatase indoxyl-nitroblue tetrazolium reaction. Ann. Biochem. 215:86-89.

Fallon, J.H., F.M. Leslie, and R.I. Cone (1985) Dynorphin-containing pathways in the substantia nigra and ventral tegmentum: A double labeling study using combined immunofluorescence and retrograde tracing. Neuropeptides 5:457-460.

Gerfen, C.R. (1992) The neostriatal mosaic: Multiple levels of compartmental organization. Trends Neurosci. 15:133-139.

Gerfen, C.R., T.M. Engber, L.C. Mahan, Z. Susel, T.N. Chase, F.J. Monsma, and D.R. Sibley (1990) D1 and D2 dopamine receptor-regulated gene expression of striatonigral and striatopallidal neurons. Science 250:1429 1432.

Gerfen, C.R., J.F. McGinty, and W.S.I. Young (1991) Dopamine differentially regulates dynorphin, substance $P$, and enkephalin expression in striatal neurons: In situ hybridization histochemical analysis. J. Neurosci 11:1016-1031.

Groenewegen, H.J., and F.T. Russchen (1984) Organization of the efferent projections of the nucleus accumbens to pallidal, hypothalamic, and mesencephalic structures: A tracing and immunohistochemical study in the cat. J. Comp. Neurol. 223:347-367.

Groenewegen, H.J., E. Vermeulen-Van der Zee, and A. te Kortschot (1987) Organization of the projections from the subiculum to the ventral striatum in the rat. A study using anterograde transport of Phaseolus vulgaris-leucoagglutinin. Neuroscience 23:103-120.

Groenewegen, H.J., H.W. Berendse, G.E. Meredith, S.N. Haber, P. Voorn, J.G. Wolters, and A.H.M. Lohman (1991) Functional anatomy of the ventral, limbic system-innervated striatum. In P. Willner and J. ScheelKruger (eds.): The Mesolimbic Dopamine System: From Motivation to Action. London: John Wiley and Sons, Ltd., pp. 19-59.

Gundersen, H.J.G., P. Bagger, T.F. Bendtsen, S.M. Evans, L. Korbo, N. Marcussen, A. Moller, K. Nielsen, J.R. Nyengaard, B. Pakkenberg, F.B Sorensen, A. Vesterby, and M.J. West (1988) The new stereological tools: Disector, fractionator, nucleator, and point sampled intercepts and their use in pathological research and diagnosis. APMIS 96:857-881.

Haber, S.N., and W.J.H. Nauta (1983) Ramifications of the globus pallidus in the rat as indicated by patterns of immunohistochemistry. Neuroscience $9: 245-260$.

Haber, S.N., and S.J. Watson (1985) The comparative distribution of enkephalin, dynorphin and substance $P$ in the human globus pallidus and basal forebrain. Neuroscience 14:1011-1024.

Haber, S.N., H.J. Groenewegen, E.A. Grove, and W.J.H. Nauta (1985) Efferent connections of the ventral pallidum: Evidence of a dual striato pallidofugal pathway. J. Comp. Neurol. 235:322-335.

Harrison, M.B., R.G. Wiley, and G.F. Wooten (1992) Changes in D2 but not D1 receptor binding in the striatum following a selective lesion of striatopallidal neurons. Brain Res. 590:305-310.

Heimer, L., and G.F. Alheid (1991) Piecing together the puzzle of basal forebrain anatomy. In T.C. Napier, P.W. Kalivas, and I. Hanin (eds.): The Basal Forebrain: Anatomy to Function. New York: Plenum Press, pp. 1-42.

Heimer, L., R.D. Switzer, and G.W. Van Hoesen (1982) Ventral striatum and ventral pallidum. Components of the motor system? Trends Neurosci. 5:83-87.

Heimer, L., D.S. Zahm, L. Churchill, P.W. Kalivas, and C. Wohltmann (1991) Specificity in the projection patterns of accumbal core and shell in the rat. Neuroscience 41:89-125.

Herkenham, M., S. Moon Edley, and J. Stuart (1984) Cell clusters in the nucleus accumbens of the rat, and the mosaic relationship of opiate receptors, acetylcholinesterase and subcortical afferent terminations. Neuroscience 11:561-593.

Jongen-Relo, A.L., H.J. Groenewegen, and P. Voorn (1993) Evidence for a multi-compartmental histochemical organization of the nucleus accumbens in the rat. J. Comp. Neurol. 337:267-276.

Kalivas, P.W., L. Churchill, and M.A. Klitenick (1993) GABA and enkephalin projection from the nucleus accumbens and ventral pallidum to the ventral tegmental area. Neuroscience 57:1047-1060.

Koob, G.F., N.R. Swerdlow, F. Vaccarino, C. Hubner, L. Pulvirenti, and F. Weiss (1991) Functional output of the basal forebrain. In T.C. Napier, P.W. Kalivas, and I. Hanin (eds.): The Basal Forebrain: Anatomy to Function. New York: Plenum Press, pp. 291-305.
Le Moine, C., E. Normand, A.F. Guitteny, B. Fouque, R. Teoule, and B. Bloch (1990) Dopamine receptor gene expression by enkephalin neurons in rat forebrain. Proc. Natl. Acad. Sci. USA 87:230-234.

Le Moine, C., E. Normand, and B. Bloch (1991) Phenotypical characterization of the rat striatal neurons expressing the D1 dopamine receptor gene. Proc. Natl. Acad. Sci. USA 88:4205-4209.

Lester, J., S. Fink, N. Aronin, and M. DiFiglia (1993) Colocalization of D1 and D2 dopamine receptor mRNAs in striatal neurons. Brain Res. 621:106-110.

Levesque, D., J. Diaz, C. Pilon, M.P. Martres, B. Giros, E. Souil, D. Schott, J.L. Morgat, J.C. Schwartz, and P. Sokoloff (1992) Identification, characterization, and localization of the dopamine D3 receptor in rat brain using 7-[$\left.{ }^{3} \mathbf{H}\right]$ hydroxy-N,N-di-n-propyl-2-aminotetralin. Proc. Natl. Acad. Sci. USA 89:8155-8159.

Levey, A., S. Hersch, D. Rye, R. Sunahara, H. Niznik, C. Kitt, D. Price, R. Maggio, M. Brann, and B. Ciliax (1993) Localization of D1 and D2 dopamine receptors in brain with subtype-specific antibodies. Proc. Natl. Acad. Sci. USA 90:8861-8865.

Mansour, A., and S.J. Watson (1995) Dopamine receptor expression in the central nervous system. In F.E. Bloom and D.J. Kupfer (eds.): Psychopharmacology: The Fourth Generation of Progress. New York: Raven Press, Ltd. pp. 207-219.

Mansour, A., J.H. Meador-Woodruff, J.R. Bunzow, O. Civelli, H. Akil, and S.J. Watson (1990) Localization of dopamine D2 receptor mRNA and D1 and $\mathrm{D} 2$ receptor binding in the rat brain and pituitary: An in situ hybridization-receptor autoradiographic analysis. J. Neurosci. 10:25872600 .

Mansour, A., J.H. Meador-Woodruff, Q.-Y. Zhou, O. Civelli, H. Akil, and S.J. Watson (1991) A comparison of DI receptor binding and mRNA in rat brain using receptor autoradiographic and in situ hybridization techniques. Neuroscience 45:359-371.

McDonald, A.J. (1991) Topographical organization of amygdaloid projections to the caudatoputamen, nucleus accumbens, and related striatal-like areas of the rat brain. Neuroscience 44:15-33.

McGonigle, P., R.P. Artvmvshvn, S. McElligott, M.P. Kung, and H. Kung (1993) Determination of dopamine D3 receptor distribution in rat brain using [125I]7-trans-OH-PIPAT. Soc. Neurosci. Abstr. 2:1369.

Meador-Woodruff, J.H., A. Mansour, J.R. Bunzow, H.H.M. Van Tol, S.J. Watson, and O. Civelli (1989) Distribution of D2 dopamine receptor mRNA in rat brain. Proc. Natl. Acad. Sci. USA 86:7625-7628.

Meador-Woodruff, J.H., A. Mansour, D.J. Healy, R. Kuehn, Q.-Y. Zhou, J.R. Bunzow, H. Akil, O. Civelli, and S.J. Watson (1991) Comparison of the distributions of $\mathrm{D} 1$ and $\mathrm{D} 2$ dopamine receptor mRNAs in rat brain. Neuropsychopharmacology 5:231-242.

Meador-Woodruff, J.H., A. Mansour, D.K. Grandy, S.P. Damask, O. Civelli, and S.J. Watson (1992) Distribution of D5 dopamine receptor mRNA in rat brain. Neurosci. Lett. 145:209-212.

Murray, A.M., H. Ryoo, and J.N. Joyce (1992) Visualization of dopamine D3-like receptors in human brain with [ ${ }^{125}$ Ilepidepride. Eur. J. Pharmacol, $227: 443-445$.

Phillipson, O.T., and A.C. Griffiths (1985) The topographic order of inputs to accumbens in the rat. Neuroscience 16:275-296.

Paxinos, G., and C. Watson (1986) The rat brain in stereotaxic coordinates. Orlando: Acaemic Press, Inc.

Pollack, A.E., M.B. Harrison, G.F. Wooten, and J.S. Fink (1993) Differential localization of A2 adenosine receptor MRNA with D1 and D2 dopamine receptor mRNA in striatal output pathways following a selective lesion of striatonigral neurons. Brain Res. 631:161-166.

Reiner, A., and K.D. Anderson (1990) The patterns of neurotransmitter and neuropeptide cooccurrence among striatal projection neurons: Conclusions based on recent findings. Brain Res. Rev. 15:251-265.

Schafer, M.K.-H., R. Day, M.R. Ortega, H. Akil, and S.J. Watson (1990) Proenkephalin messenger RNA is expressed both in the rat anterior and posterior pituitary. Neuroendocrinology 51:444-448.

Shippenberg, T.S., and A. Herz (1987) Place preference conditioning reveals the involvement of D1-dopamine receptors in the motivational properties of $\mu$ - and $\kappa$-opioid agonists. Brain Res. 436:169-172.

Shippenberg, T.S., and A. Herz (1988) Motivational effects of opioids: Influence of D-1 vs. D-2 receptor antagonists. Eur. J. Pharmacol. 151:233-242.

Shippenberg, T.S., R. Bals-Kubik, A. Huber, and A. Herz (1991) Neuroanatomical substrates mediating the aversive effects of D-1 dopamine receptor antagonists. Psychopharmacology 103:209-214. 
Sokoloff, P., B. Giros, M.P. Martres, M.L. Bouthenet, and J.C. Schwartz (1990) Molecular cloning and characterization of a novel dopamine receptor (D3) as a target for neuroleptics. Nature 347:146-151.

Sokoloff, P., M.P. Martres, B. Giros, M.L. Bouthenet, and J.C. Schwartz (1992) The third dopamine receptor (D3) as a novel target for antipsychotics. Biochem. Pharmacol. 43:659-666.

Sunahara, R.K., H.C. Guan, B.F. O’Dowd, P. Seeman, L.G. Laurier, G. Ng, S.R. George, J. Torchia, H.H.M. Van Tol, and H.B. Niznik (1991) Cloning of the gene for a human dopamine D5 receptor with higher affinity for dopamine than D1. Nature 350:614-619.

Surmeier, D.J., J. Eberwine, C.J. Wilson, Y. Cao, A. Stefani, and S.T. Kitai (1992) Dopamine receptor subtypes colocalize in rat striatonigral neurons. Proc. Natl. Acad. Sci. USA 89:10178-10182.

Surmeier, D.J., A. Reiner, M.S. Levine, and M.A. Ariano (1993) Are neostriatal dopamine receptors colocalized? Trends Neurosci. 16:299 305.

Van Tol, H.H.M., J.R. Bunzow, H.C. Guan, R.K. Sunahara, P. Seeman, H.B. Niznik, and O. Civelli (1991) Cloning of the gene for a human D4 receptor with high affinity for the antipsychotic clozapine. Nature 350:610-614.

Voorn, P., C.R. Gerfen, and H.J. Groenewegen (1989) Compartmental organization of the ventral striatum of the rat: Immunohistochemical distribution of enkephalin, substance $P$, dopamine, and calcium-binding protein. J. Comp. Neurol. 289:189-201.

Watson, S., P. Patel, S. Burke, J. Herman, M. Schafer, and S. Kwak (1988) In situ hybridization of mRNA in nervous tissue: A primer. In A. Sundermann (ed.): Society for Neuroscience Short Course 1 Syllabus. Washington, DC: Society for Neuroseience, pp. 4-29.
White, N.M., M.G. Packard, and N. Hiroi (1991) Place conditioning with dopamine D1 and D2 agonists injected peripherally or into nucleus accumbens. Psychopharmacology 103:271-276.

Wise, R.A., and D.C. Hoffman (1992) Localization of drug reward mechanisms by intracranial injections. Synapse 10:247-263.

Yoshikawa, K., C. Williams, and S.L. Sabol (1984) Rat brain preproenkephalin mRNA: cDNA cloning, primary structure, and distribution in the central nervous system. J. Biol. Chem. 259:14301-14308.

Zaborsky, L., G.F. Alheid, M.C. Beinfeld, L.E. Eiden, L. Heimer, and M. Palkovits (1985) Cholecystokinin innervation of the ventral striatum: A morphological and radioimmunological study. Neuroscience 14:427453.

Zahm, D.S., and J.S. Brog (1992) On the significance of subterritories in the "accumbens" part of the rat ventral striatum. Neuroscience 50:751-767.

Zahm, D.S., and L. Heimer (1988) Ventral striatopallidal parts of the basal ganglia in the rat: I. Neurochemical compartmentation as reflected by the distributions of neurotensin and substance $\mathbf{P}$ immunoreactivity. $J$. Comp. Neurol. 272:516-535.

Zahm, D.S., and L. Heimer (1990) Two transpallidal pathways originating in the rat nucleus accumbens. J. Comp. Neurol. 302:437-446.

Zahm, D.S., and L. Heimer (1993) Specificity in the efferent projections of the nucleus accumbens in the rat: Comparison of the rostral pole projection patterns with those of the core and shell. J. Comp. Neurol. $327: 220-232$.

Zhou, Q.Y., D.K. Grandy, L. Thambi, J.A. Kushner, H.H.M. Van Tol, R. Cone, D. Pribnow, J. Salon, J.R. Bunzow, and O. Civelli (1990) Cloning and expression of human and rat D1 dopamine receptors. Nature $347: 76-80$. 